\title{
Macroalgae contribute to nested mosaics of pH variability in a subarctic fjord
}

\author{
D. Krause-Jensen ${ }^{1,2}$, C. M. Duarte ${ }^{3,4}$, I. E. Hendriks ${ }^{5}$, L. Meire ${ }^{6,7,8}$, M. E. Blicher ${ }^{6}$, N. Marbà ${ }^{5}$, and M. K. Sejr ${ }^{1,2}$ \\ ${ }^{1}$ Arctic Research Centre, Bioscience, Aarhus University, C.F. Møllers Allé 8, 8000 Århus C, Denmark \\ ${ }^{2}$ Department of Bioscience, Aarhus University, Vejlsøvej 25, 8600 Silkeborg, Denmark \\ ${ }^{3}$ Red Sea Research Center, King Abdullah University of Science and Technology, Thuwal 23955-6900, \\ Saudi Arabia \\ ${ }^{4}$ Faculty of Biosciences, Fisheries and Economics, University of Troms $\varnothing$, Troms $\emptyset$, Norway \\ ${ }^{5}$ Department of Global Change Research, IMEDEA (CSIC-UIB) Instituto Mediterráneo de Estudios Avanzados, \\ Miquel Marqués 21, 07190 Esporles, Spain \\ ${ }^{6}$ Greenland Climate Research Centre, Greenland Institute of Natural Resources, Kivioq 2, Box 570, \\ 3900 Nuuk, Greenland \\ ${ }^{7}$ Marine Biology Laboratory, University of Ghent (UGent), Krijgslaan 281 (S8), 9000 Ghent, Belgium \\ ${ }^{8}$ Royal Netherlands Institute of Sea Research (NIOZ), Department of Ecosystem Studies, Korringaweg 7, \\ 4401 NT, Yerseke, the Netherlands
}

Correspondence to: D. Krause-Jensen (dkj@bios.au.dk)

Received: 10 February 2015 - Published in Biogeosciences Discuss.: 27 March 2015

Revised: 4 August 2015 - Accepted: 4 August 2015 - Published: 19 August 2015

\begin{abstract}
The Arctic Ocean is considered the most vulnerable ecosystem to ocean acidification, and large-scale assessments of $\mathrm{pH}$ and the saturation state for aragonite $\left(\Omega_{\mathrm{arag}}\right)$ have led to the notion that the Arctic Ocean is already close to a corrosive state. In high-latitude coastal waters the regulation of $\mathrm{pH}$ and $\Omega_{\mathrm{arag}}$ is, however, far more complex than offshore because increased biological activity and input of glacial meltwater affect $\mathrm{pH}$. Effects of ocean acidification on calcifiers and non-calcifying phototrophs occupying coastal habitats cannot be derived from extrapolation of current and forecasted offshore conditions, but they require an understanding of the regimes of $\mathrm{pH}$ and $\Omega_{\text {arag }}$ in their coastal habitats. To increase knowledge of the natural variability in $\mathrm{pH}$ in the Arctic coastal zone and specifically to test the influence of benthic vegetated habitats, we quantified $\mathrm{pH}$ variability in a Greenland fjord in a nested-scale approach. A sensor array logging $\mathrm{pH}, \mathrm{O}_{2}$, PAR, temperature and salinity was applied on spatial scales ranging from kilometre scale across the horizontal extension of the fjord; to $100 \mathrm{~m}$ scale vertically in the fjord, 10-100 m scale between subtidal habitats with and without kelp forests and between vegetated tidal pools and adjacent vegetated shores; and to centimetre to
\end{abstract}

metre scale within kelp forests and millimetre scale across diffusive boundary layers of macrophyte tissue. In addition, we assessed the temporal variability in $\mathrm{pH}$ on diurnal and seasonal scales. Based on $\mathrm{pH}$ measurements combined with point samples of total alkalinity, dissolved inorganic carbon and relationships to salinity, we also estimated variability in $\Omega_{\text {arag }}$. Results show variability in $\mathrm{pH}$ and $\Omega_{\text {arag }}$ of up to $0.2-$ 0.3 units at several scales, i.e. along the horizontal and vertical extension of the fjord, between seasons and on a diel basis in benthic habitats and within $1 \mathrm{~m}^{3}$ of kelp forest. Vegetated intertidal pools exhibited extreme diel $\mathrm{pH}$ variability of $>1.5$ units and macrophyte diffusive boundary layers a $\mathrm{pH}$ range of up to 0.8 units. Overall, pelagic and benthic metabolism was an important driver of $\mathrm{pH}$ and $\Omega_{\text {arag }}$ producing mosaics of variability from low levels in the dark to peak levels at high irradiance generally appearing favourable for calcification. We suggest that productive coastal environments may form niches of high $\mathrm{pH}$ in a future acidified Arctic Ocean. 


\section{Introduction}

The Arctic Ocean is considered to be the most vulnerable ecosystem to ocean acidification (OA) due to the combined effects of low temperature, which increases the solubility of $\mathrm{CO}_{2}$ and, in places, dilution of the buffering capacity of seawater by freshwater inputs (Fabry et al., 2009; AMAP, 2013). Indeed, large-scale assessments of $\mathrm{pH}$ in combination with saturation states for aragonite $\left(\Omega_{\text {arag }}\right)<1$ have led to the notion that the Arctic Ocean is already close to a corrosive state (Fabry et al., 2009). However, whereas this has been documented for offshore waters, the Arctic contains a massive coastline where the regulation of $\mathrm{pH}$ and $\Omega_{\text {arag }}$ is far more complex than that offshore (Hofmann et al., 2011; Duarte et al., 2013). In coastal waters, the role of air-sea $\mathrm{CO}_{2}$ exchange in regulating $\mathrm{pH}$ operates along with watershed effects driven by the discharge of freshwater and the effects of metabolically intense communities on $\mathrm{pH}$ (Duarte et al., 2013). The Greenland Ice Sheet is melting at a rate that has more than doubled in the last decade (Helm et al., 2014) and Greenland fjords are hence potentially among the most susceptible to the effects of freshening and acidification.

As most calcifiers occupy coastal habitats, the assessment of risks of Arctic acidification to these vulnerable species cannot be derived from extrapolation of the current and forecasted offshore conditions alone, requiring instead an understanding of the regimes of $\mathrm{pH}$ and $\Omega_{\mathrm{arag}}$ in the coastal habitats they occupy, and the same is true regarding potential effects of ocean acidification on coastal phototrophs (calcifying or non-calcifying) (Mercado and Gordillo, 2011). Such information is currently largely lacking for the Arctic in general and for Greenland in particular, which calls for efforts to understand variability in $\mathrm{pH}$ in the coastal zone informing on the factors controlling $\mathrm{pH}$ and ultimately determining the sensitivity of the coastal Arctic Ocean ecosystem to ocean acidification.

Greenland has a vast and highly indented coastline, extending approximately $44000 \mathrm{~km}$ and representing ca. $12 \%$ of the world's coastline (Krause-Jensen and Duarte, 2014). This coastline forms a complex network of fjords and open coasts that contains multiple features contributing to heterogeneity, such as continental ice and freshwater discharge at the headwaters, variable slopes and substrates, differential water residence time conducive to widely distinct temperature regimes within neighbouring areas (Olesen et al., 2015), and tides that generate intertidal habitats and force flow patterns. In addition, Greenland fjords often support highly productive kelp forests (Krause-Jensen et al., 2012) and intertidal seaweed communities (Høgslund et al., 2014), which have been suggested to have the capacity to affect $\mathrm{pH}$ and $\Omega_{\text {arag }}$ locally (Krause-Jensen and Duarte, 2014). Such effects have been demonstrated for Antarctic and temperate kelp/macroalgal ecosystems (Middelboe and Hansen 2007; Delille et al., 2009; Cornwall et al., 2013a) as well as for subtropical and tropical seagrass meadows (e.g. Hofmann et al., 2011; Hendriks et al., 2014). Calcifiers such as bivalves, brittle stars and sea urchins, which are potentially vulnerable to OA, are ecologically important as they contribute significantly to carbon cycling in both the subarctic and Arctic Greenland, where their distribution ranges from the intertidal zone to $>300 \mathrm{~m}$ depth (Sejr et al., 2002; Blicher et al., 2007, 2009, 2013; Blicher and Sejr, 2011). Phototrophs such as kelps, while being able to affect the $\mathrm{pH}$ regime, may also respond to $\mathrm{OA}$, which has been shown to stimulate their growth (Olischläger et al., 2012) and affect the competition between kelps and understory red algae (Connell and Russell 2010).

Although the variability in $\mathrm{pH}$ and $\Omega_{\mathrm{arag}}$ in Greenland fjords has not been reported, available oceanography and environmental surveys suggest that this may be substantial. For instance, in Young Sound, Sejr et al. (2011) found that the extent of sea-ice cover and inputs of glacial melt water affect seawater $p \mathrm{CO}_{2}$ levels and sea-air exchange at spatial, seasonal and interannual scales. Seasonal dynamics of autotrophic and heterotrophic plankton metabolism have also been found to markedly affect $p \mathrm{CO}_{2}$ levels in Kobbefjord, a subarctic fjord in SW Greenland (Sejr et al., 2014). However, information on scales of variability in $\mathrm{pH}$ and $\Omega_{\text {arag }}$ in Greenland fjords is still lacking, precluding the assessment of their current and future vulnerability to ocean acidification.

Here we quantify pH variability in Kobbefjord, SW Greenland. This subarctic fjord supports dense and productive subtidal kelp forests, intertidal macroalgal habitats and high abundance of bivalves and sea urchins with important roles in the ecosystem (Blicher et al., 2009; Krause-Jensen et al., 2012). We hypothesize that Kobbefjord contains a mosaic of $\mathrm{pH}$ environments nested across a range of scales of variability and that primary production in general, and by macroalgae in particular, may be an important driver of $\mathrm{pH}$ variability relevant for benthic calcifiers. We first assess seasonal and spatial variability in the open-water $\mathrm{pH}$ at the kilometre scale along the horizontal extension and at $100 \mathrm{~m}$ scale vertically in the fjord. We then examine diel variability in $\mathrm{pH}$ within subtidal benthic habitats colonized by kelp forest or microalgae/scattered filamentous algae as well as in vegetated tidal pools and adjacent vegetated intertidal shores, with the distance between parallel deployments at the $10-100 \mathrm{~m}$ scale. We further explore the $\mathrm{pH}$ variability three-dimensionally at centimetre to metre scale within the kelp forest ecosystem and at millimetre scale across the diffusive boundary layer (i.e. the layer in which molecular diffusion is the dominant transport mechanism for dissolved material; see e.g. de Beer and Larkum, 2001) of key macrophyte species. Whereas our assessment focuses on $\mathrm{pH}$, we also discuss the associated variability in $\Omega_{\text {arag }}$. 

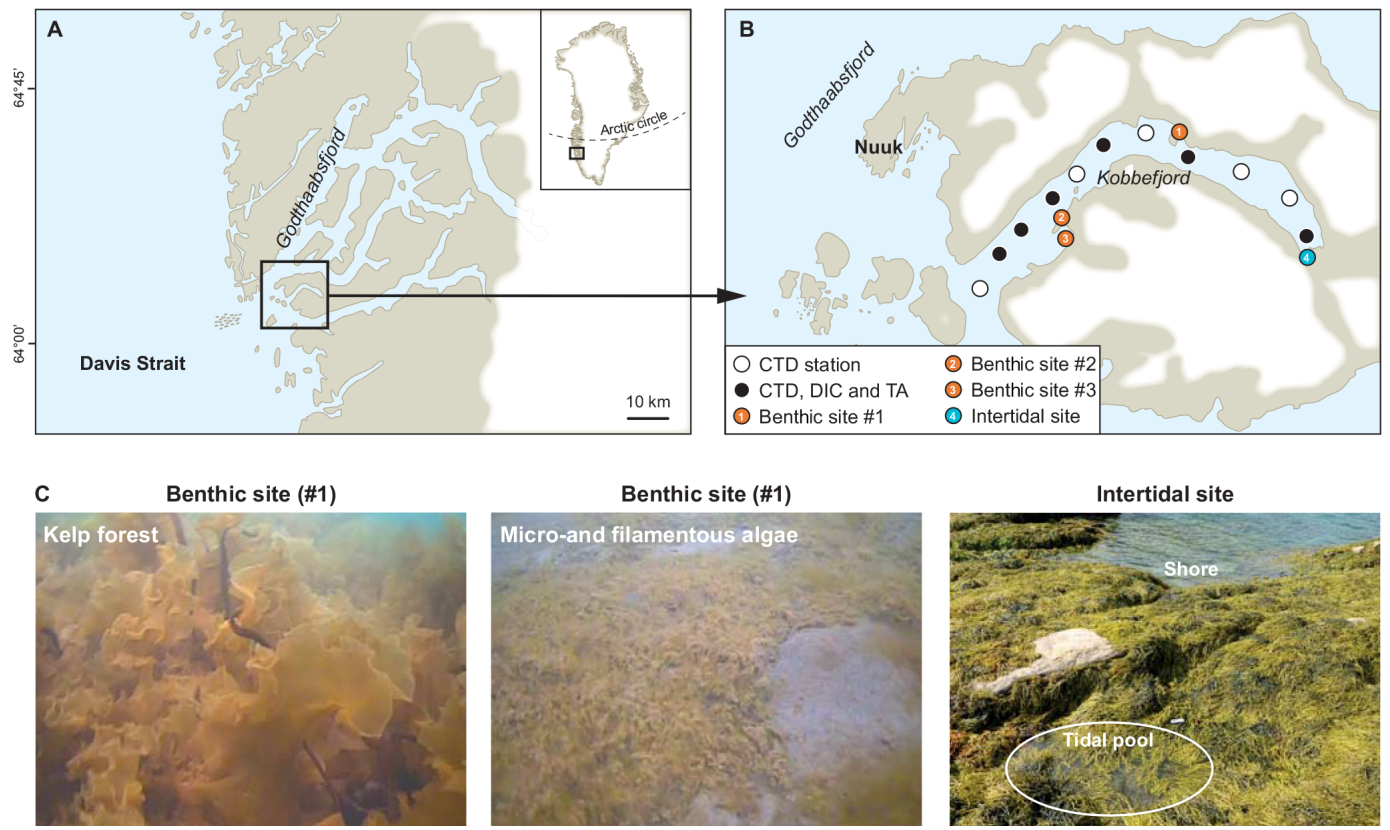

Figure 1. (a) Location of Kobbefjord, Nuuk. (a) Location of sampling sites in Kobbefjord: fjord-scale sites (CTD, $C_{\mathrm{T}}, A_{\mathrm{T}}$ : filled circles; CTD: open circles), vegetated subtidal sites (open circles \#1-3), and intertidal sites (open circles \#4). (c) Photopanel of benthic habitats: a typical kelp forest habitat (dominated by Saccharina longicruris) and habitat colonized by microalgae/scattered filamentous algae (example from site \#1, representative of sites \#1-3 in map) and a vegetated intertidal pool and the adjacent vegetated shore dominated by Ascophyllum nodosum and Fucus spp. (site \#4 in map).

\section{Methods}

\subsection{Study area}

Kobbefjord is located in the extensive Godthåbsfjord system in southwest Greenland (Fig. 1a). The fjord is $17 \mathrm{~km}$ long and $0.8-2 \mathrm{~km}$ wide and has a maximum depth of $150 \mathrm{~m}$. It is subjected to marked exchange of coastal water driven by a tidal range of $1-4.5 \mathrm{~m}$ (Richter et al., 2011) and receives freshwater mainly from a river in the innermost part of the fjord, leading to a salinity gradient in the surface water. Sea ice usually covers the inner part of the fjord from December to early May, but the outer part of the fjord is permanently ice-free. Light attenuation in the water column has been reported to range from $0.083 \mathrm{~m}^{-1}$ in February to $0.197 \mathrm{~m}^{-1}$ in May to $0.135 \mathrm{~m}^{-1}$ in September (Sejr et al., 2014). Whereas the phytoplankton community is the main primary producer in the central parts of the fjord (Sejr et al., 2014), subtidal macroalgae, dominated by Saccharina longicruris and Agarum clathratum, form productive benthic habitats along the shores to water depths of ca. $40 \mathrm{~m}$ (KrauseJensen et al., 2012) interspaced with communities of benthic microalgae (Glud et al., 2010; Attard et al., 2014) as well as with scattered eelgrass (Zostera marina) meadows at 1$3 \mathrm{~m}$ depth (Olesen et al., 2015). Communities of intertidal macroalgae, dominated by Fucus spp. and Ascophyllum nodosum, are prominent in the intertidal zone, where they form an important habitat for blue mussels, for example (Blicher et al., 2013).

Three field campaigns targeting seasonal- and fjord-scale variability in $\mathrm{pH}$ in the pelagic zone were conducted in the spring (19 April), midsummer (18 July) and late summer (3 September) of 2013 (Fig. 1b). The late summer survey was associated with an intensive campaign (27 August-6 September 2013) exploring $\mathrm{pH}$ variability in shallow subtidal kelp habitats and neighbouring habitats colonized by benthic microalgae and scattered filamentous algae (Fig. 1c). A final late summer campaign (22-30 August 2014) addressed $\mathrm{pH}$ variability in vegetated tidal pools and surface waters of adjacent vegetated shores (Fig. 1c). All pH data from fjord-scale to microscale are reported on the total $\mathrm{pH}$ scale.

\subsection{Fjord- and seasonal-scale $\mathrm{pH}$ variation}

To determine the large-scale spatial and seasonal variation in physical and chemical parameters in the water column of Kobbefjord, vertical profiles were performed at 11 stations located along a longitudinal gradient following the main central axis of the fjord on 19 April, 18 July, and 3 September 2013 (Fig. 1b). We used a Sea-Bird CTD (SBE 19plus) equipped with sensors for temperature, conductivity, fluorescence (Seapoint chlorophyll fluorometer), oxygen (SBE 43, Sea-Bird) and pH (SBE 18, Sea-Bird). Alongside CTD profiles, water samples were collected using a $5 \mathrm{~L}$ Niskin bottle at $1,5,10,20,30$, and $40 \mathrm{~m}$ depth. Water was collected 
for dissolved oxygen measurement using Winkler titration (Parsons et al., 1984), which was used to calibrate the CTD oxygen optode. The $\mathrm{pH}$ sensor was calibrated using NIST buffers and a seawater Tris buffer prepared according to Dickson (2007). Unfiltered water was transferred to $150 \mathrm{~mL}$ borosilicate glass bottles for $\mathrm{pH}$ analysis. The samples were poisoned with a saturated mercuric chloride solution, cooled and stored in darkness until arrival. Back in the lab, $\mathrm{pH}$ was measured potentiometrically using a glass reference electrode (Orion, Ross Ultra pH/ATC Triode) calibrated with NIST buffers and a seawater Tris buffer prepared according to Dickson (2007). The measurements were used to correct the offset of the SBE $18 \mathrm{pH}$ measurements.

For estimation of the saturation state of aragonite ( $\left.\Omega_{\text {arag }}\right)$, samples for analyses of dissolved inorganic carbon $\left(C_{\mathrm{T}}\right)$ and total alkalinity $\left(A_{\mathrm{T}}\right)$ were collected at five stations on one occasion (3 September 2013). Triplicate $12 \mathrm{~mL}$ samples were collected at 5, 10, 20,30, and $40 \mathrm{~m}$ depth and near the bottom. Samples were carefully siphoned through Tygon tubing from Niskin bottles to $12 \mathrm{~mL}$ septum-capped glass vial (Exetainers), allowing the water to overflow for two volume changes. The samples were poisoned with $100 \mu \mathrm{L} 5 \%$ $\mathrm{HgCl}_{2}$ to avoid biological alteration. $C_{\mathrm{T}}$ was analysed with a $C_{\mathrm{T}}$ analyser (AS-C3, Apollo SciTech Inc). The accuracy of the analysis was $2.4 \mu \mathrm{mol} \mathrm{kg} \mathrm{kg}^{-1}$ (average numerical deviation from the reference material value) and the precision was $1.4 \mu \mathrm{mol} \mathrm{kg}{ }^{-1}$ (average standard deviation of triplicate samples). $A_{\mathrm{T}}$ was analysed on an alkalinity titrator (ASALK2 from Apollo SciTech), with verification against the same certified reference material used for $\mathrm{pH}$ measurements or a Metrohm Titrando 808 by open-cell titration (Dickson et al., 2007) using Batch 136 supplied by the Andrew Dickson lab at UC San Diego for verification. Average analysis accuracy was $2.9 \mu \mathrm{mol} \mathrm{kg}{ }^{-1}$ (average numerical deviation from the reference material value). Relationships between the point samples of $A_{\mathrm{T}}$ and salinity $(S)$ were used to verify the published relationship for the Godthåbsfjord system $(\mathrm{TA}=159+63 \mathrm{~S}$; Meire et al., 2015), which was subsequently applied for estimation of $A_{\mathrm{T}}$ for the full September data set. $\Omega_{\text {arag }}$ and $p \mathrm{CO}_{2}$ were calculated from $A_{\mathrm{T}}$ and $\mathrm{pH}$ using the $\mathrm{CO}_{2} \mathrm{SYS}$ Excel program version 2.1 (Pierrot et al., 2006) with the $K_{1}$ and $K_{2}$ constants from Mehrbach et al. (1973), as modified by Dickson and Millero (1987).

\subsection{Small-scale and diurnal-scale $\mathrm{pH}$ variation}

To measure small-scale and diurnal-scale variation in $\mathrm{pH}$ and physico-chemical variables in kelp forests and adjacent subtidal habitats colonized by microalgae and scattered filamentous algae we constructed metal frames measuring approximately $0.90 \mathrm{~m} \times 0.90 \mathrm{~m} \times 1.10 \mathrm{~m}$. Each frame was equipped with instruments that allowed continuous measurements of temperature, salinity, water level, oxygen concentration, photosynthetically active radiation (PAR) and $\mathrm{pH}$ at ca. $50 \mathrm{~cm}$ above the seafloor (Fig. A1). Measurements were made ev- ery $10 \mathrm{~min}$ or less. We selected three dense (close to $100 \%$ cover) kelp beds located in shallow water (average depth $2-$ $5 \mathrm{~m}$ ) in different sites of the fjord. All kelp beds were dominated by $S$. longicruris with co-occurrence of A. clathratum and were surrounded by habitats colonized by microalgae and varying amounts of scattered filamentous algae. We conducted parallel deployments of frames with loggers in kelp beds vs. surrounding non-kelp habitats in each of the three sites, with each deployment lasting about $48 \mathrm{~h}$. The typical distance between kelp and non-kelp habitats at each site was approximately $100 \mathrm{~m}$. Conductivity, temperature and water level were measured with a Hydrolab DS5X and a MicroCAT (SBE37, Sea-Bird). Oxygen concentration was measured using miniDOT oxygen loggers (Precision Measurement Engineering) and a Hydrolab DS5X. PAR was measured using Odyssey PAR loggers from Dataflow Systems Pty Limited. $\mathrm{pH}$ was measured using Hydrolab DS5X and SeaFET $\mathrm{pH}$ loggers from Satlantic. Hydrolab DS5X pH sensors were calibrated with a routine two-point calibration using NIST buffers of $\mathrm{pH}_{\mathrm{NBS}} 7.0$ and 10.0. Before and after each deployment all instruments were placed in a $50 \mathrm{~L}$ tank with seawater to intercalibrate sensors. All $\mathrm{pH}$ loggers were offset to the same newly calibrated high-precision SeaFET pH sensor, calibrated at the Satlantic facility (www.satlantic.com) on the total scale using single-point calibration. Oxygen sensors were calibrated to $\mathrm{O}_{2}$ concentrations of the tank as determined from Winkler titrations.

To monitor three-dimensional $\mathrm{pH}$ variations on a metre scale within the kelp canopy, we deployed a custom-built multi-sensor array, consisting of an autonomous data logger (dataTaker DT85) in a watertight housing (custom-built by Albatros Marine Technologies S.I.) with 16 pre-amplified $\mathrm{pH}$ electrodes (Omega, PHE-1304-NB). The $\mathrm{pH}$ sensors were attached to the submersible logger by $5 \mathrm{~m}$ long cables to allow for adjusting their position as needed (Fig. A1 in Appendix). The sensors were configured in situ in a three-dimensional array on the metal frame occupying a volume of approximately $1 \mathrm{~m}^{3}$, with four sensors at $0.1 \mathrm{~m}$ from the bottom, four sensors at $0.2 \mathrm{~m}$, four sensors just underneath the canopy and four above the canopy, which typically extended about $0.75 \mathrm{~m}$ above the seafloor. All $\mathrm{pH}$ sensors were calibrated with a three-point calibration using NIST buffers of $\mathrm{pH}_{\mathrm{NBS}}$ 4.0, 7.0 and 10.0, allowing at least $5 \mathrm{~min}$ between every reading for the sensors to stabilize. All $\mathrm{pH}$ loggers were offset to the same newly calibrated high-precision SeaFET pH sensor as mentioned above. On several occasions triplicate samples for determination of $C_{\mathrm{T}}$ and $A_{\mathrm{T}}$ were collected and analysed as described above to allow calculation of carbonate chemistry and $\Omega_{\text {arag. }}$.

$\mathrm{pH}$ variation in vegetated tidal pools dominated by Ascophyllum nodosum and adjacent intertidal habitats on the shore also dominated by A. nodosum and Fucus spp. was quantified over a diurnal cycle through sampling at low tide just after pool formation and prior to pool inundation during day and night. $\mathrm{pH}$ and $\Omega_{\text {arag }}$ were calculated from $C_{\mathrm{T}}$ and $A_{\mathrm{T}}$ 
samples collected and analysed as described above and computed using the CO2SYS program (Pierrot et al., 2006) with in situ information on temperature and salinity. Salinity was analysed from water samples based on measurements of conductivity (Orion 3-Star conductivity benchtop), while oxygen concentration and water temperature were determined using a portable meter (Hack, HQ40d).

\subsection{Microscale pH variation}

$\mathrm{pH}$ variations at a millimetre scale were measured in the laboratory on six different species of macrophytes (the intertidal brown macroalgae Ascophyllum nodosum and Fucus vesiculosus, the kelps Saccharina longicruris and Agarum clathratum, the green alga Ulva lactuca, and the seagrass Zostera marina) occurring in Kobbefjord and collected either there or, for logistic reasons, in another branch of the Godthåbsfjord system. From each species, a piece of approximately $5 \times 2 \mathrm{~cm}$ was cut and mounted on a microscope slide in an aquarium with seawater before measurements. The setup was mounted in an aquarium in a climate-controlled room with temperature kept at $2-3{ }^{\circ} \mathrm{C}$. By gently blowing the water surface above the mounted slide with air supplied by an aquarium pump, we generated a stable low current velocity of approximately $0.28 \pm 0.02$ (SE) $\mathrm{mm} \mathrm{s}^{-1}$ in our observational area. We measured $\mathrm{pH}$ from a point close to the leaf surface up until out of the diffusive boundary layer, where the $\mathrm{pH}$ was stable. We used UNISENSE micro-pH sensors with 25 or $50 \mu \mathrm{m}$ tips, connected to a volt meter with 1-decimal precision for millivolt measurements (Consort, R362). $\mathrm{pH}$ sensors were calibrated with a three-point calibration using NIST buffers of $\mathrm{pH}_{\mathrm{NBS}} 4.0,7.0$ and 10.0 before each series of measurements. After each change in species or replica, a resting period of $>15 \mathrm{~min}$ was observed to allow the diffusive boundary layer to be fully developed before measurements. A USB microscope (DinoCapture) connected to a PC with on-screen visualization software aided in visually establishing the lowest point of the measurements, as close to the macrophyte surface as possible without breaking the tip of the electrode. A scaled picture from this lowest point allowed for back-calculating the actual distance to the leaf surface afterwards. We allowed readings at this lowest point to stabilize for $>5$ min after which the millivolt value was written down manually. The microsensor was then raised $20 \mu \mathrm{m}$ with a precise 1-D micromanipulator and thereafter $30 \mu \mathrm{m}$, after which we continued with $50 \mu \mathrm{m}$ increments and then 100 and $500 \mu \mathrm{m}$ increments until a stable $\mathrm{pH}$ was obtained for three measurements or more and we considered we were outside the diffusive boundary layer; between subsequent points the sensor was allowed to stabilize for at least $5 \mathrm{~min}$. We evaluated 3 replicas of each species at a irradiance of $200 \mu \mathrm{mol}$ photons $\mathrm{m}^{-2} \mathrm{~s}^{-1}$, and calculated the $\Delta \mathrm{pH}$ across the diffusive boundary layer (defined from the tissue surface to where $\mathrm{pH}$ was at $0.99 \times$ water-column $\mathrm{pH}$ ).

\section{Results}

Data are available in digital form (Krause-Jensen et al., 2015).

\subsection{Fjord-scale and seasonal pH variability}

Large seasonal and spatial variability was observed in $\mathrm{pH}$ values along the longitudinal gradient centrally in the fjord (Fig. 2a). $\mathrm{pH}_{\mathrm{T}}$ in surface water increased in April due to $\mathrm{CO}_{2}$ consumption by the spring bloom as evidenced by a very high fluorescence (Fig. A2), to a maximum value of almost 8.50 , most pronounced in the mouth of the fjord with values of around 8.25 in the inner part (Fig. 2). Accordingly, a horizontal gradient of around $0.25 \mathrm{pH}$ units was observed along the main axis of the fjord. $\mathrm{pH}_{\mathrm{T}}$ values in upper layers decreased during the summer to around 8.35 in July and with the maximum observed towards the inner part of the fjord. A further decrease in $\mathrm{pH}$ was observed in September, with more homogenous values in surface waters along the fjord gradient resulting in a horizontal range of only $0.05 \mathrm{pH}$ units. Vertical gradients in $\mathrm{pH}$ from the surface to the deeper waters of the fjord ranged from only 0.1 units in April, when the fjord was vertically mixed, to 0.15 units in September to $0.25 \mathrm{pH}$ units in July, when maximum $\mathrm{pH}_{\mathrm{T}}$ values of 8.35 occurred in a subsurface algal bloom in the inner parts of the fjord with waters supersaturated in oxygen (up to $120 \%$ saturation, Figs. A2, A3) and minimum values of $\mathrm{pH}_{\mathrm{T}} 8.1$ were measured in the deeper sectors (Fig. 2a). Seasonally pH varied between 0.2 and 0.3 units in both surface and deep waters over the 5 months. $\Omega_{\text {arag }}$ values were closely coupled to $\mathrm{pH}$ and ranged from minimum values of 1.6 , observed in the bottom waters of the inner part of the fjord, to maximum values of 2.5 in the subsurface waters in September (Krause-Jensen et al., 2015). Corresponding $p \mathrm{CO}_{2}$ levels ranged from 162 to $325 \mu \mathrm{atm}$, in the range of values recently reported for the fjord (Sejr et al., 2014).

Oxygen saturation at the fjord-scale ranged greatly from 85 to $127 \%$ and was strongly related to $\mathrm{pH}$ for each of the three periods (Fig. 3a), pointing at strong biological control of $\mathrm{pH}$ variability within the fjord. The slope of the $\mathrm{pH}$ versus $\mathrm{O}_{2}$ relationship was steepest for the April survey, when the highest $\mathrm{pH}$ levels were observed. Examination of $\mathrm{pH}$ values in relation to fluorescence and temperature also showed that the warmest waters, of up to $10^{\circ} \mathrm{C}$, observed in July, supported intermediate $\mathrm{pH}$, while the highest $\mathrm{pH}$ was observed in the coldest waters, corresponding to the April survey, when temperatures were uniformly low across the fjord (Fig. 3b). On a vertical scale, the cold bottom waters with low fluorescence generally supported the lowest $\mathrm{pH}$ values across seasons. Hence, overall, $\mathrm{pH}$ showed much tighter correlation with $\mathrm{O}_{2}$ levels than with water temperature, and the correlation between $\mathrm{pH}$ and $\mathrm{O}_{2}$ implied a similar close correlation between $\Omega_{\text {arag }}$ and $\mathrm{O}_{2}$ levels. 


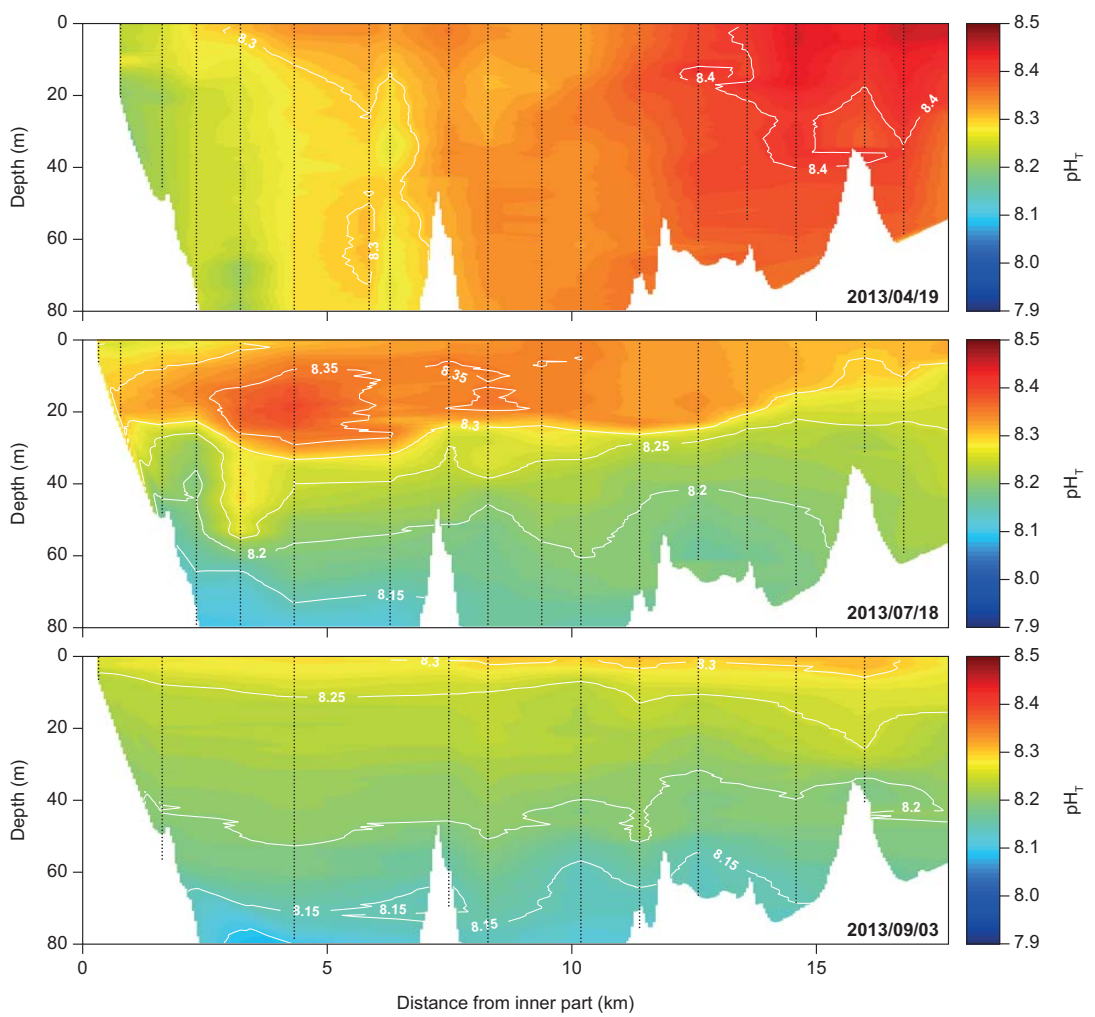

Figure 2. Fjord-scale pH variability in Kobbefjord on 19 April, 18 July and 3 September 2013.
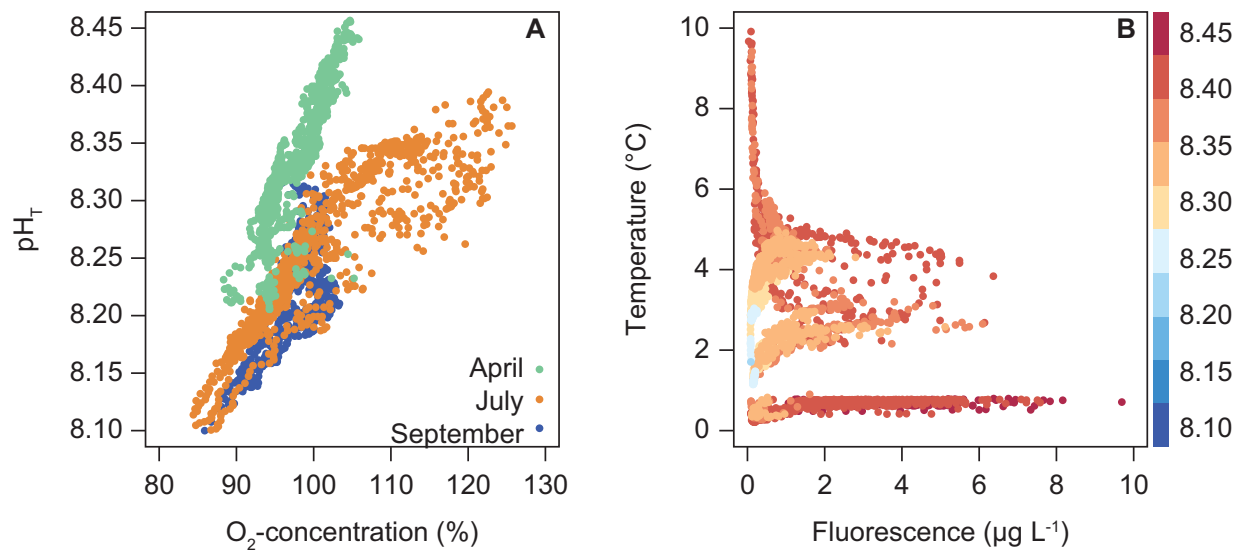

Figure 3. Fjord-scale relationships in Kobbefjord between $\mathrm{pH}$ and oxygen (a), and between temperature and fluorescence with associated pH levels shown with symbol colour (b), on three sampling occasions: 19 April, 18 July and 3 September 2013.

\subsection{Small-scale and diurnal pH variability in kelp forests and benthic habitats colonized by microalgae/scattered filamentous algae}

The three parallel deployments in kelp forest and habitats colonized by microalgae and scattered filamentous algae encompassed six complete diurnal cycles which exhibited peak $\mathrm{pH}_{\mathrm{T}}$ levels during the day of 8.11 (8.04-8.19) (avg. (SD)) and $8.08(8.02-8.16)$, respectively, as opposed to minimum
$\mathrm{pH}_{\mathrm{T}}$ levels during night of 8.02 (7.97-8.06) and 8.01 (7.94$8.09)$, respectively, with no significant difference between habitats $(t$ test, $p>0.05)$. The diurnal range of minimum night $\mathrm{pH}$ to maximum day $\mathrm{pH}$ was slightly higher in the kelp forest (avg. $\pm \mathrm{SD}=0.098 \pm 0.061)$ than above the microalgae/filamentous algae $(0.073 \pm 0.052)$ (paired, one-tailed $t$ test, $p=0.041$ ).

There were large differences in the extent of diel fluctuations in $\mathrm{pH}$ among deployments dependent on incident irra- 

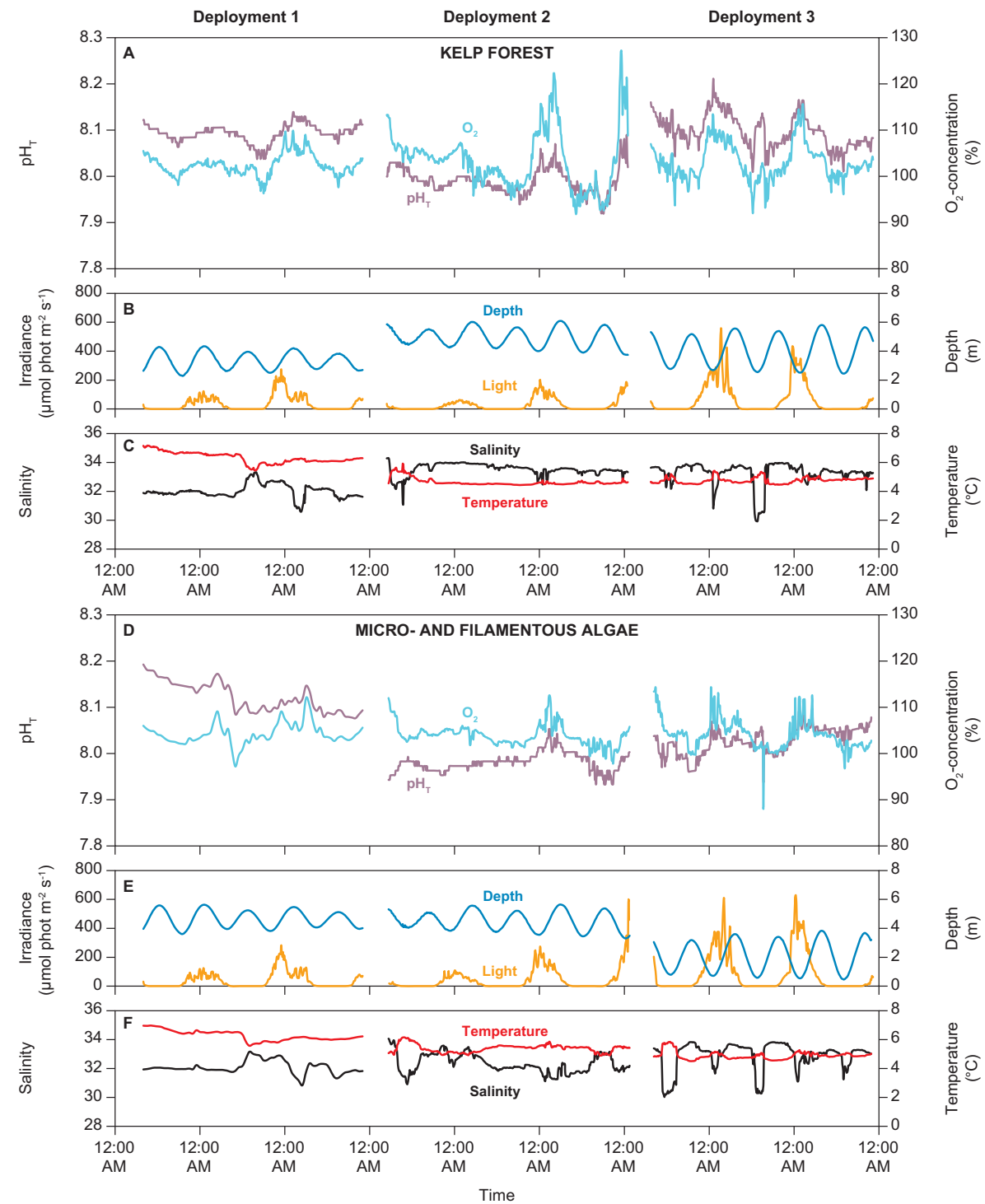

Figure 4. Diurnal variability in $\mathrm{pH}, \mathrm{O}_{2}$, water depth (all measured by Hydrolab) and irradiance (measured by Odyssey loggers) at ca. $50 \mathrm{~cm}$ above the seafloor in kelp forests (a-c) and habitats colonized by microalgae/filamentous algae (e-f) during three parallel deployment in Kobbefjord, Nuuk, 27-30 August, 30 August-2 September, and 2-5 September 2013. The deployments represent the benthic sites (\#1-3, respectively) shown on the map (Fig. 1).

diance and the shifting phase of tidal state and the solar cycle (Fig. 4). Diel pH fluctuations were small during dark, cloudy days and when high tide coincided with peak solar radiation, thereby reducing incident irradiance on the benthic habitat. In contrast, diel $\mathrm{pH}$ fluctuations were amplified in deployments during sunny days when low tide coincided with peak solar radiation (Fig. 4). Hence, the interaction between tide and the solar cycle controlled incident radiation and thereby induced fluctuations in photosynthetic activity and $\mathrm{pH}$. This was particularly apparent in kelp forests where peak daily $\mathrm{pH}$ increased as a function of maximum daily photosynthetic solar radiation reaching the habitat during the day, whereas this relationship was not significant in the water column above the microalgae/filamentous algae (Fig. 5). Indeed, biologic control of $\mathrm{pH}$ was also reflected in strong relationships between $\mathrm{pH}$ and $\mathrm{O}_{2}$ concentration within each deployment in the kelp forests $\left(R^{2}=0.64-0.76\right)$, particularly during high irradiance, as opposed to weaker $\mathrm{pH}$ versus $\mathrm{O}_{2}$ relationships for the microalgae/filamentous algae sites $\left(R^{2}=0.05-0.15\right)$ which also showed much smaller variability in $\mathrm{O}_{2}$ levels $(98$ $114 \%$ saturation) than did the kelp forest (92-128\% saturation) (Fig. 6). The diurnal range of $\mathrm{O}_{2}$ concentrations in the kelp forest matched the range recorded at pelagic fjord scale on a seasonal basis (85-127\%, Fig. 3).

Tidal changes in water masses, reflected by changes in salinity and temperature, also contributed to variations in 


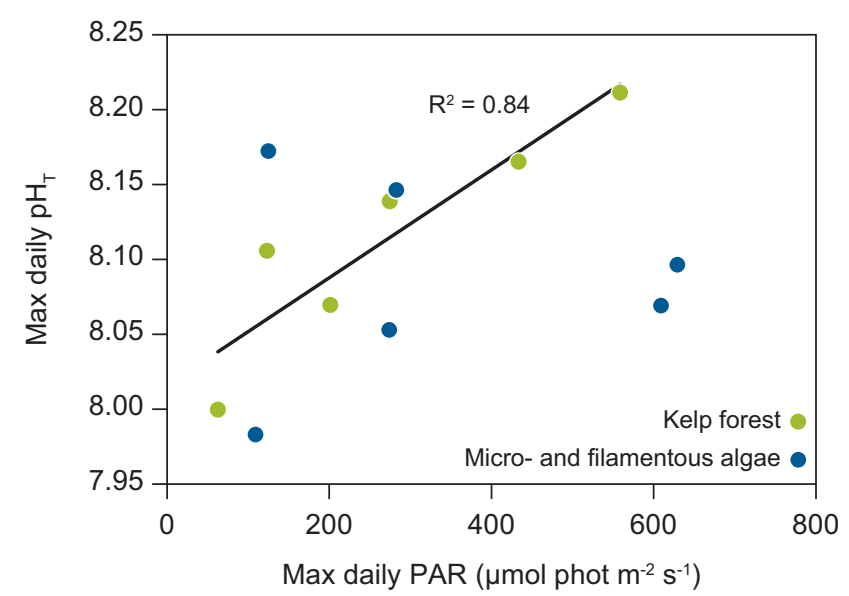

Figure 5. Maximum daily $\mathrm{pH}$ in a kelp forest (green dots) and above microalgae/filamentous algae (blue dots) as a function of maximum daily incident light over 6 full days as measured during three parallel deployments in Kobbefjord, Nuuk, 27-30 August, 30 August2 September, and 2-5 September 2013. Linear fit and coefficient of determination are shown for the significant relationship for the kelp forest.

$\mathrm{pH}$ and $\mathrm{O}_{2}$ levels. This was visible as incidences of sudden changes in $\mathrm{pH}$ paralleling fluctuations in salinity and also as differences in $\mathrm{pH}$ levels between deployments in water masses of different salinity (Fig. 4). However, salinity explained much less of the variation in $\mathrm{pH}$ than did $\mathrm{O}_{2}$, except in one deployment in the microalgae/filamentous algae habitat when salinity explained $51 \%$ of the variation in $\mathrm{pH}$ as opposed to $15 \%$ explained by $\mathrm{O}_{2}\left(R^{2}=0.04-0.33\right.$ in kelp forest; $R^{2}=0.04-0.51$ in microalgae/filamentous algae, data not shown). Thus, overall biological activity had a much stronger influence on $\mathrm{pH}$ than had exchange of water masses.

The observed diurnal $\mathrm{pH}$ variability also translated into important fluctuations in $\Omega_{\text {arag }}$, involving $0.18 \pm 0.06$ units (from maximum day levels of $1.77 \pm 0.21$ to minimum night levels of $1.60 \pm 0.17$ ) in the kelp forest and $0.14 \pm 0.07 \Omega_{\text {arag }}$ units (from maximum day levels of $1.72 \pm 0.30$ to minimum night levels of $1.58 \pm 0.26$ ) at the microalgae/filamentous algae sites. Corresponding $p \mathrm{CO}_{2}$ levels ranged from 238 to $536 \mu \mathrm{atm}$ at the kelp sites and from 258 to $515 \mu \mathrm{atm}$ at the microalgal/filamentous algal sites.

\subsection{Metre- to millimetre-scale $\mathrm{pH}$ variability in kelp forests}

Examination of the variability in $\mathrm{pH}$ within $1 \mathrm{~m}^{3}$ kelp forest, sampled from the bottom of the canopy to the overlying water column, using the multi-electrode array, showed very large concurrent $\mathrm{pH}$ variability involving about 0.2 to $0.3 \mathrm{pH}$ unit differences at any given time and with a total $\mathrm{pH}_{\mathrm{T}}$ range of 7.76-8.36 across deployments (Fig. 7). In general, pH tended to be highest at the top of the canopy and in the water just above the canopy, reflecting that the canopy top is the

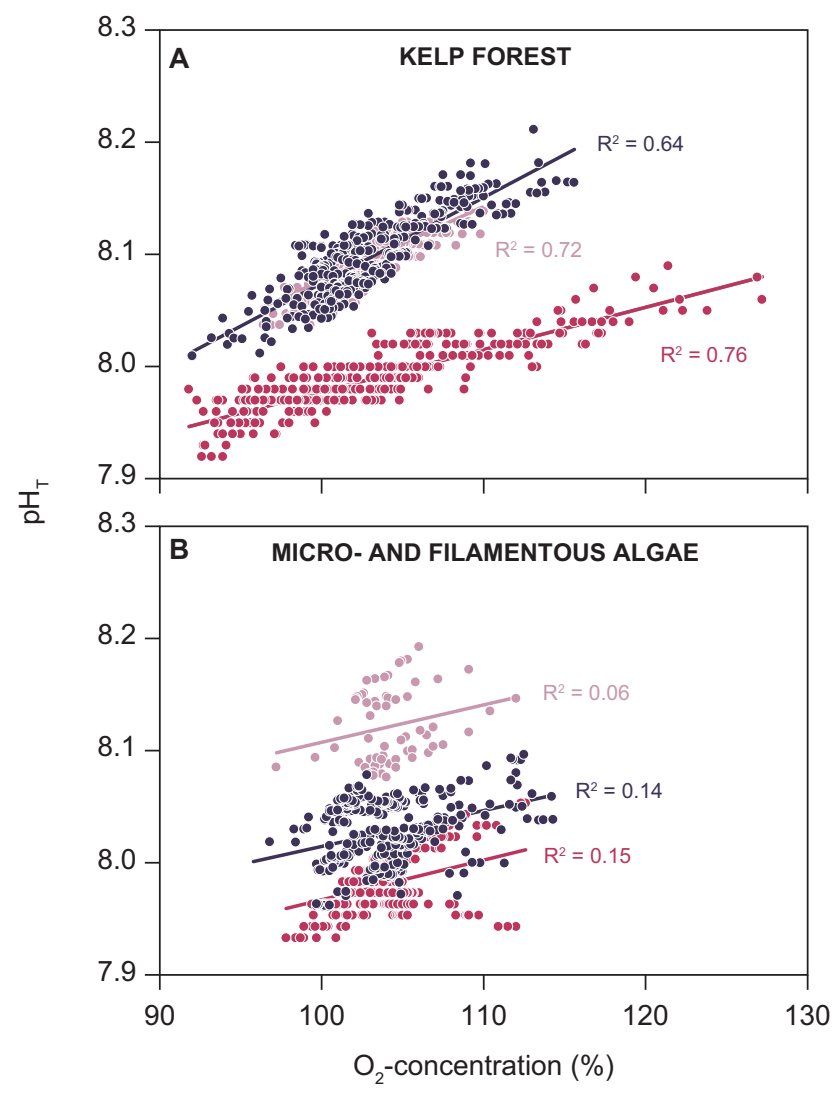

Figure 6. $\mathrm{pH}$ vs. $\mathrm{O}_{2}$ concentration for three parallel deployments (\#1-3 shown by increasing colour intensity) in subtidal habitats colonized by kelp forests (top panel) or microalgae/scattered filamentous algae (bottom panels) in Kobbefjord, Nuuk, AugustSeptember 2013. Each deployment represents 10 min loggings by multiloggers (Hydrolab) over ca. two diurnal cycles. Linear fits and coefficients of determination are shown.

most photosynthetically active layer, while $\mathrm{pH}$ was generally lower in the shaded bottom part of the canopy (Fig. 7), where photosynthetic biomass and incident irradiance are lower and respiration rates higher. The range of $\mathrm{pH}$ within $1 \mathrm{~m}^{3}$ of kelp forest at any one point in time was comparable among deployments, despite the different light conditions, although the absolute values of $\mathrm{pH}$ differed among deployments, with highest levels observed at peak incident irradiance (Fig. 7). This small-scale variability in $\mathrm{pH}$ also translated into a variability in $\Omega_{\text {arag }}$ of about 0.20 units in $1 \mathrm{~m}^{3}$ of habitat at any time.

$\mathrm{pH}$ also varied significantly within the diffusive boundary layer of the six macrophyte species examined in the light (Fig. 8a), with $\mathrm{pH}$ increasing by $0.07-0.85$ units, depending on species, from the top of the $0.3-2.2 \mathrm{~mm}$ thick diffusive boundary layer to the surface of the plants (Fig. 8b). 


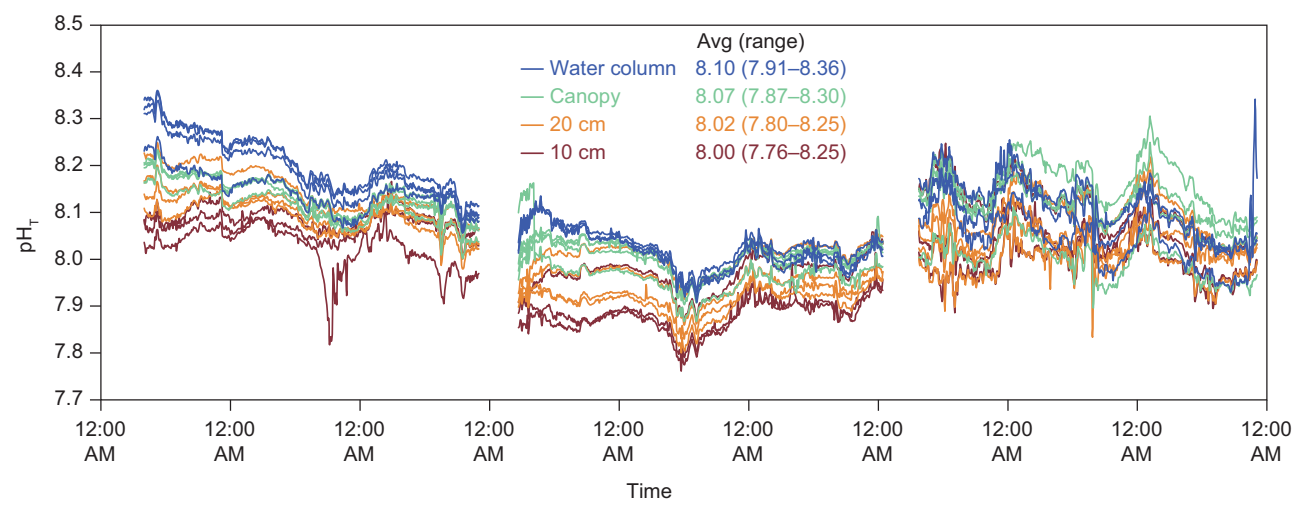

Figure 7. $\mathrm{pH}$ variability within $1 \mathrm{~m}^{3}$ of kelp forest in Kobbefjord, Nuuk, during three deployments in late August-September 2013. Sixteen $\mathrm{pH}$ sensors were configured in situ in a 3-day array with four sensors at $0.1 \mathrm{~m}$ from the bottom, four sensors at $0.2 \mathrm{~m}$, four sensors just underneath the canopy and four in the water column above the canopy, which typically extended about $0.75 \mathrm{~m}$ above the seafloor.

\section{4 pH variability in intertidal pools}

$\mathrm{pH}$ and oxygen concentration showed important diel variability in vegetated intertidal pools, with oxygen supersaturation (up to $176 \%$ ) during the day and undersaturation (down to $11 \%$ ) at night, compared to far more uniform concentrations in the surface waters on the adjacent vegetated shore (89$111 \%$ saturation, Fig. 9). Accordingly, $\mathrm{pH}_{\mathrm{T}}$ changed greatly in intertidal pools, reaching maximum values of 9.0 during the day and minimum values of 7.4 during night periods, i.e. a diel range of ca. $1.6 \mathrm{pH}$ units. Diel $\mathrm{pH}$ fluctuations in the surface waters of the adjacent shore were much smaller (8.0 8.5) but still high, reflecting the metabolic activity of the intertidal vegetation growing on the shore (Fig. 9). The difference in $\mathrm{pH}$ between vegetated intertidal pools and adjacent shores provided an additional example of variability in $\mathrm{pH}$ between adjacent habitats.

\section{Discussion}

Our results highlight the nested scales of variability in $\mathrm{pH}$ present in the Kobbefjord ecosystem involving (1) seasonal variability, largely driven by the phytoplankton spring bloom as a major event affecting $\mathrm{pH}$; (2) diel variability acting through complex changes in submarine irradiance modulating rates of photosynthesis and respiration of benthic vegetation driven by the interaction of the solar and the tidal cycles; (3) large-scale variability along horizontal and vertical fjord gradients reflecting gradients in metabolic activity in combination with movement of water masses; (4) variability between subtidal habitats with and without kelp forests and between vegetated tidal pools and adjacent vegetated shores reflecting variable degrees of biological control; (5) smallscale three-dimensional variability due to heterogeneity in metabolic processes and mixing in vegetated habitats; and (6) microscale variability across the diffusive boundary layer of macrophytes (Fig. 10).
Overall, metabolic processes played a fundamental role in driving $\mathrm{pH}$ variability across scales, as reflected in strong relationships between oxygen concentration and $\mathrm{pH}$ at the fjord scale and at both diel and seasonal scales. Primary producers played a major role in the regulation of $\mathrm{pH}$ variability, both in the pelagic zone, where in particular the intense spring bloom characteristic of Arctic ecosystems (Takahashi et al., 2003; Sejr et al., 2014) induced high pH in the subsurface layers while the respiratory process in the bottom waters reduced $\mathrm{pH}$, and in the nearshore benthic environment, where the presence of subtidal kelp forests and intertidal macroalgae induced marked spatial and diurnal variability in $\mathrm{pH}$. The mosaics of $\mathrm{pH}$ reflected that the density of the primary producers, and the spatio-temporal separation of photosynthesis and ecosystem respiration in combination with mixing of water masses were key drivers of the variability in both planktonic and benthic communities. Hence, the vertical gradient of declining $\mathrm{pH}$ from upper illuminated to lower shaded habitats varied from the $10-100 \mathrm{~m}$ scale in the planktonic community where the density of primary producers is relatively low to the centimetre to metre scale in dense kelp forests. The same is true on a temporal scale where the diurnal $\mathrm{pH}$ variation in the benthic vegetation matches the seasonal variability in $\mathrm{pH}$ in the planktonic community.

The scale of seasonal $\mathrm{pH}$ variability in the planktonic community (Fig. 10) compared well with previous reports for the Arctic, showing the spring bloom as a prevalent driver of $p \mathrm{CO}_{2}$ (Sejr et al., 2011; Meire et al., 2015). Though a multitude of factors including water depth, light regime, season, seawater retention time, density and plant species may all affect $\mathrm{pH}$ variability in vegetated habitats, our results match evidence from other latitudes of strong $\mathrm{pH}$ variability in macroalgal forests and seagrass meadows. Hence, marked diel $\mathrm{pH}$ variability has also been reported from a Californian kelp forest (Frieder et al., 2012), from a Mediterranean seagrass bed (Hendriks et al., 2014), and, in an extreme case, from a temperate, shallow, dense algal bed (diel range: ca. 1 

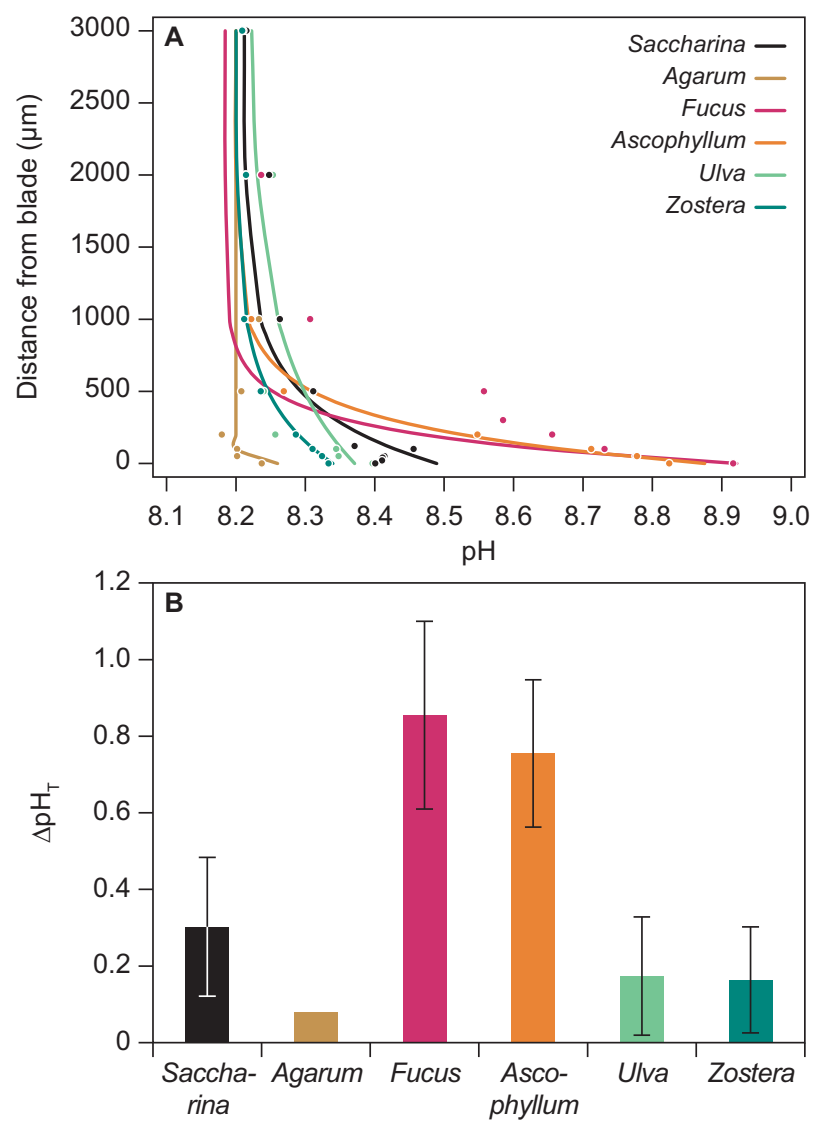

Figure 8. Microscale $\mathrm{pH}$ variability across diffusive boundary layers of blades of six different macrophyte species illuminated by $200 \mu \mathrm{mol}$ photons $\mathrm{m}^{-2} \mathrm{~s}^{-1}$ : the kelps Saccharina longicruris and Agarum clathratum, the intertidal brown macroalgae Fucus vesiculosus and Ascophyllum nodosum, the green macroalga Ulva lactuca, and the seagrass Zostera marina. (a) pH levels (mean of 2-3 replicate measurements) across blade diffusive boundary layers fitted by an exponential model $\left(y=y 0+a \times \exp ^{-b \times x}, R^{2}>0.90\right.$ for all individual fits). (b) $\mathrm{pH}$ range across the diffusive boundary layer of the various species.

unit; Middelboe and Hansen, 2007) and kelp forest (diel range: ca. 0.6-0.8 pH units; Cornwall et al., 2013a). Our pH measurements in benthic habitats neighbouring the kelp forest also carried a biological signal, though less distinct, likely reflecting the combined signal of the benthic primary producers at the site, of the neighbouring kelp forests, and of the planktonic community in the water masses exchanged with tidal currents. The marked biological control of $\mathrm{pH}$ in kelp forests suggests that diel $\mathrm{pH}$ may be even more pronounced during sunny days with more intense photosynthesis than during the generally overcast conditions of our survey. Thus, while the identified $\mathrm{pH}$ range and $\mathrm{pH}$ vs. $\mathrm{O}_{2}$ relationships for the planktonic community covered the full growth season, they solely represented a few overcast September days in the benthic habitats and would likely involve markedly
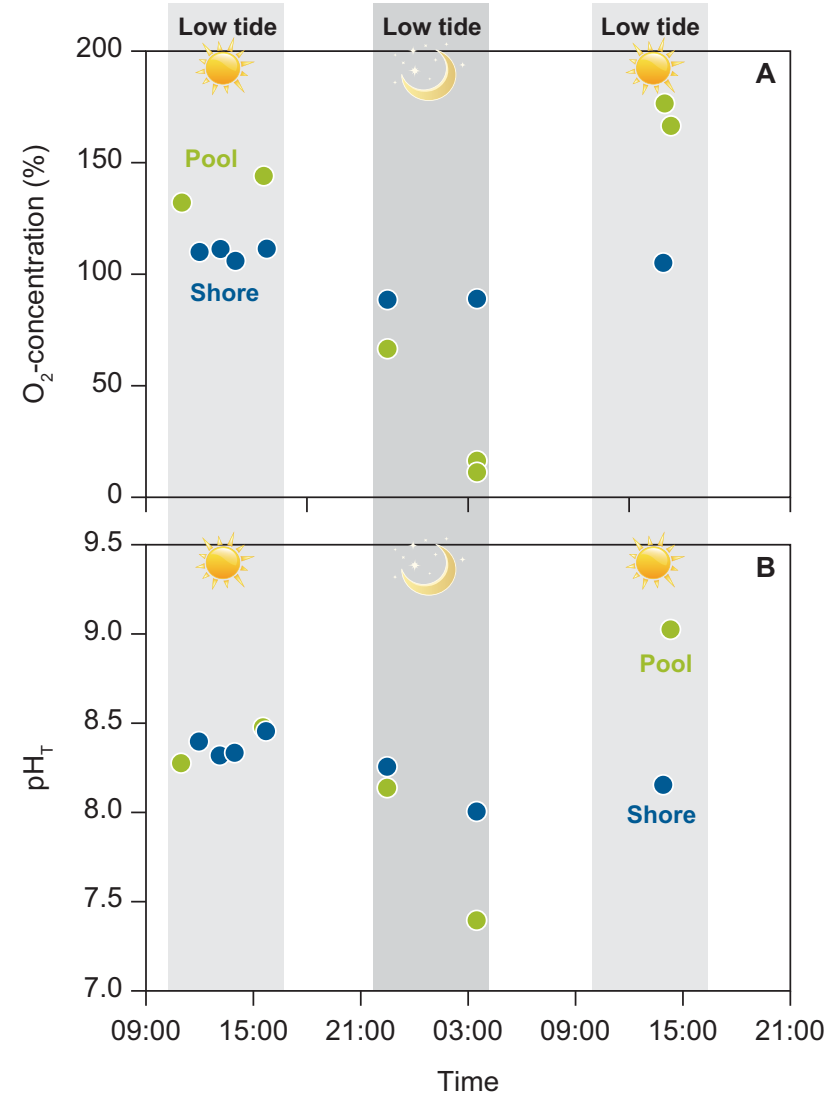

Figure 9. $\mathrm{O}_{2}$ concentration and $\mathrm{pH}$ in vegetated tidal pools and in surface waters of neighbouring vegetated intertidal shores measured at low tide during day and night just after pool formation and before pool inundation.

higher levels had they covered the full growth season. For subantarctic giant kelp forests, the diel amplitude in $p \mathrm{CO}_{2}$ and $C_{\mathrm{T}}$ (Delille et al., 2009) during spring and summer, as well as the seasonal amplitude in $\mathrm{pH}, C_{\mathrm{T}}$ and $p \mathrm{CO}_{2}$ (Delille et al., 2000), was reported to be markedly higher within kelp forests as compared with unvegetated habitats, underlining the kelps' strong biological control of $\mathrm{pH}$.

We further show, for the first time, significant 3-D variability in $\mathrm{pH}$ within $1 \mathrm{~m}^{3}$ of kelp forest, with $\mathrm{pH}$ ranging about $0.2-0.3 \mathrm{pH}$ units at any one point in time and a total variability across deployments of $7.76-8.36 \mathrm{pH}_{\mathrm{T}}$, resembling the range recorded across the entire growth season in the pelagic. Levels of $\mathrm{pH}$ were dependent on the position in the kelp canopy, with the highest $\mathrm{pH}$ generally appearing at the top of the canopy and decreasing toward the seafloor, likely reflecting the vertical structure of photosynthetic activity in the kelp bed. The fast rates of metabolic activity in combination with reduced flow in such densely vegetated habitats make these 3-D patterns appear in spite of the marked exchange of water masses resulting from the $1-4.5 \mathrm{~m}$ tidal range. 


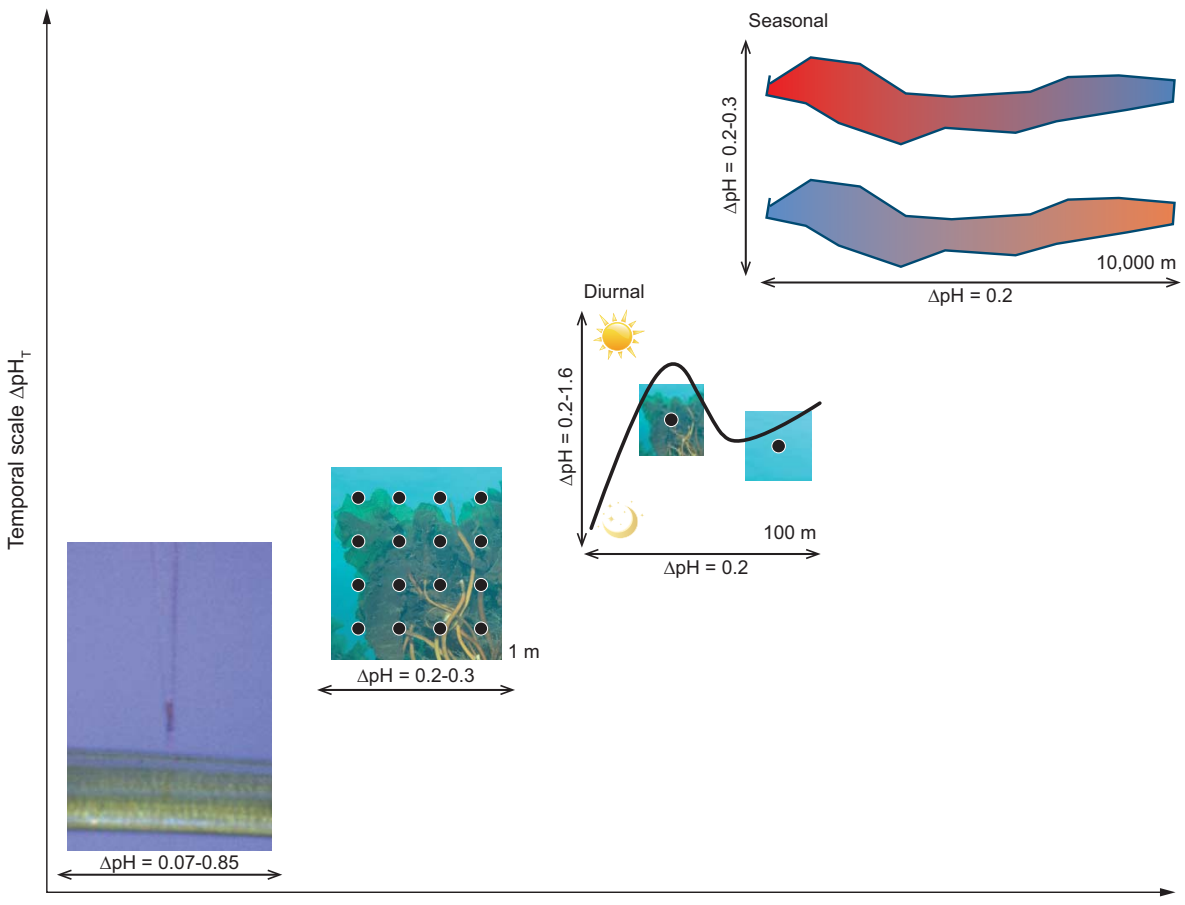

Spatial scale $\Delta \mathrm{pH}_{\mathrm{T}}$

Figure 10. Conceptual summary of nested scales of temporal and spatial variability in $\mathrm{pH}$ in Kobbefjord, Nuuk. The figure shows the maximum $\mathrm{pH}$ range at the various scales examined. From lower left to upper right: (1) microscale variability across macrophyte diffusive boundary layers, (2) small-scale variability within kelp forests, (3) diurnal variability in vegetated subtidal habitats and intertidal pools/adjacent shores and variability between habitats at the $100 \mathrm{~m}$ scale, and (4) seasonal and fjord-scale horizontal variability.

Changes in $\mathrm{pH}$ were particularly pronounced in small tidal pools, where photosynthesis of dense seaweed stands of primarily Ascophyllum nodosum and Fucus spp. drove $\mathrm{O}_{2}$ levels to large supersaturation levels $(176 \%)$ and forced $\mathrm{pH}$ to extremes of up to $\mathrm{pH}_{\mathrm{T}} 9.0$ at low tide during sunny days, corresponding to $\Omega_{\text {arag }}$ of 4.14 and $p \mathrm{CO}_{2}$ of $13 \mu \mathrm{atm}$ compared to night values of $\mathrm{pH}_{\mathrm{T}} 7.4, \Omega_{\mathrm{arag}}$ of 0.27 and $p \mathrm{CO}_{2}$ of $1647 \mu$ atm driven by community respiration, which almost depleted $\mathrm{O}_{2}$ in the pools (11\% saturation). In surface waters of adjacent densely vegetated intertidal shores, we observed a maximum $\mathrm{pH}_{\mathrm{T}}$ of 8.5 with corresponding $\Omega_{\mathrm{arag}} 2.23$ and $p \mathrm{CO}_{2}$ of $96 \mu$ atm during the day and a minimum $\mathrm{pH}_{\mathrm{T}}$ of 8.0, with corresponding $\Omega_{\text {arag }}$ of 0.54 and $p \mathrm{CO}_{2}$ of $243 \mu$ atm during the night. While intertidal brown macroalgae thrive in such habitats when regularly flushed as in the current study, apparently only Ulva (Enteromorpha) intestinalis occurs in isolated, rarely flushed rock pools, where it can drive $\mathrm{pH}$ to levels > 10 (Björk et al., 2004).

At the microscale, $\mathrm{pH}$ also showed considerable variability with a range of up to $0.85 \mathrm{pH}$ units across the diffusive boundary layer of the key species of the vegetated shallow ecosystems, with high $\mathrm{pH}$ levels at the tissue surface declining towards the bulk water during daytime (Fig. 8). There was substantial variability among species, with intertidal macroalgae (Ascophyllum and Fucus) showing the largest $\mathrm{pH}$ range. The interspecific differences likely related to the species' photosynthetic rates as well as to their morphology, which affect the thickness of the diffusive boundary layer (Hurd and Pilditch, 2011). This microscale pH variability across the diffusive boundary layer compared well with previous observations for the calcifying alga Halimeda discoidea ( $\mathrm{pH}$ range of 0.7 across diffusive boundary layer; de Beer and Larkum, 2001) as well as for the coralline algae Sporolithon durum (light-dark $\mathrm{pH}$ change at tissue surface 0.9; Hurd et al., 2011) and Arthrocardia corymbosa ( $\mathrm{pH}$ range across diffusive boundary layer 0.4 , for example, depending on flow; Cornwall et al., 2013b). The pH range across the diffusive boundary layer of Ulva was surprisingly low considering the ability of Ulva to elevate $\mathrm{pH}$ to high levels (Björk et al., 2004), but it was probably the combination of low water temperature and limited nutrient supply that limited the photosynthetic rate. The diffusive boundary layer thickness as well as the $\mathrm{pH}$ range across it depends markedly on flow conditions. Reduced flows as present in dense vegetation increase the diffusive boundary layer thickness and consequently the $\mathrm{pH}$ range (Hurd et al., 2011; Cornwall et al., 2013b). The current experiment was, hence, conducted at reduced flow and, importantly, at the same flow for all species. Exchange of water masses with different salinity and temperature also added to the variability in $\mathrm{pH}$ as indicated for both 
pelagic (Fig. 3b) and benthic (Fig. 4) systems but showed much weaker correlation to $\mathrm{pH}$ than did $\mathrm{O}_{2}$ concentrations reflecting the biological control.

The processes above resulted in nested scales of $\mathrm{pH}$ variability in the Kobbefjord ecosystem (Fig. 10), with variability ranging $0.2-0.85$ units across spatial scales and 0.2-1.6 units over diurnal to seasonal scales. This variability provides a dynamic mosaic of niches for organisms. Niches of high $\mathrm{pH}$ may be particularly important for the more vulnerable larval and juveniles stages of calcifiers under conditions of low $\mathrm{pH}$ as projected for the future (Kroecker et al., 2013). The suitability for calcifiers is best represented by $\Omega_{\text {arag }}$, where calcifiers should be favoured by high $\Omega_{\text {arag }}$ values. The Kobbefjord ecosystems host a number of calcifying species, including bivalves such as blue mussels, scallops and snails; echinoderms such as green sea urchins; crustaceans such as Pseudobalanus balanoides; and calcareous algae and foraminifers. Overall, the identified $\Omega_{\text {arag }}$ conditions were well above 1, particularly in illuminated habitats with intense photosynthesis and, hence, indicated favourable conditions for calcification. The phytoplankton spring bloom, depleting $\mathrm{CO}_{2}$ and driving $\Omega_{\text {arag }}$ to values close to 3 , would also provide adequate conditions for pelagic calcifiers, as it would provide the double benefit of adequate environments for aragonite deposition and food supply to support growth and the energetic demands of calcifiers. Canopies of kelp and intertidal seaweed environments may also provide adequate niches for calcifiers during summer, when $\Omega_{\text {arag }}$ values would be highest through the cumulative action of the processes upregulating $\mathrm{pH}$ and $\Omega_{\text {arag }}$ values discussed above. Indeed, most calcifiers spawn and recruit in early summer (Arendt et al., 2013), when $p \mathrm{CO}_{2}$ remains low, warmer water temperatures lead to higher $\Omega_{\text {arag }}$ and high solar radiation and a long photoperiod allow seaweeds to draw down $\mathrm{CO}_{2}$ further (Delille et al., 2000).

The upregulating effect of primary producers on $\mathrm{pH}$ is counterbalanced by the opposite effect of respiration and decomposition prevailing in shaded and deeper basins and periods as illustrated by the large-scale seasonal variability in the pelagic community (Fig. 2), and paralleled in kelp forests outside the productive period (Delille et al., 2009) as well as during night-time and in shaded layers of the kelp forest (Fig. 7) and tidal pools (Fig. 9). These shaded habitats with diurnally low $\Omega_{\text {arag }}$ could be challenging habitats for calcifiers. Interestingly, however, blue mussels grew in close association with macroalgae even in intertidal pools, where they would experience maximum $\Omega_{\text {arag values of up }}$ to 4.28 when low tide occurred at noon as opposed to levels as low as 0.28 during night (Fig. 9). Blue mussels have indeed been observed to abound in intertidal macroalgal habitats (Blicher et al., 2013) and along with other calcifiers to be trophically linked with habitat-forming algae such as Ascophyllum (Riera et al., 2009), and have also been reported to tolerate high $p \mathrm{CO}_{2}$ concentrations when food is abundant (Thomsen et al., 2013). The recurring periods of high $\Omega_{\mathrm{arag}}$ in combination with adequate food supply can likely compensate for the potential problems of low $\Omega_{\text {arag }}$ during night. Laboratory experiments have demonstrated that semidiurnal fluctuations of $0.3 \mathrm{pH}$ units may compensate for negative effects of constantly low $\mathrm{pH}$ on the development of mussel larvae (Frieder et al., 2014). Calcareous epiphytic organisms, such as encrusted algae and bryozoans, would also experience high variability in $\Omega_{\text {arag }}$ at the surface of the plant tissue, where periodically high $\Omega_{\text {arag }}$ values favours calcification, as elegantly demonstrated by de Beer and Larkum (2001).

The existence of a mosaic of environments in the Kobbefjord underlines the importance of metabolic processes along with habitat configuration and interactions among community constituents in affecting $\mathrm{pH}$ in coastal ecosystems as opposed to the simpler situation in the open ocean (Duarte et al., 2013; Hendriks et al., 2014). This pronounced influence of metabolic processes occurs in spite of Kobbefjord being a macrotidal area with marked exchange of water masses with the coastal region and is probably also the case in many other shallow coastal areas in the Arctic, as has also been highlighted for areas in the temperate zone (Duarte et al., 2013). While the current study explored $\mathrm{pH}$ in benthic habitats under overcast situations in the early autumn of the subarctic, kelp forests are likely to induce much more pronounced increases in $\mathrm{pH}$ and $\Omega_{\text {arag }}$ in midsummer, when irradiances are higher and the photoperiod longer, and further north, during high-Arctic midsummer, when the sun does not set for months. Under scenarios of ocean acidification such vegetated habitats may gain increased importance as local refuges for calcifiers. The projected poleward expansion of macrophytes into the Arctic with warming and reduced sea-ice cover (Müller et al., 2009; Jueterbock et al., 2013) has been hypothesized to provide such niches of elevated $\mathrm{pH}$ and $\Omega_{\text {arag }}$ during summer (Krause-Jensen et al., 2014). Similarly, increased pelagic primary production as forecasted for parts of the Arctic Ocean (Arrigo et al., 2008; Slagstad et al., 2011; Popova et al., 2012) may also create local niches of high $\mathrm{pH}$. 


\section{Appendix A}
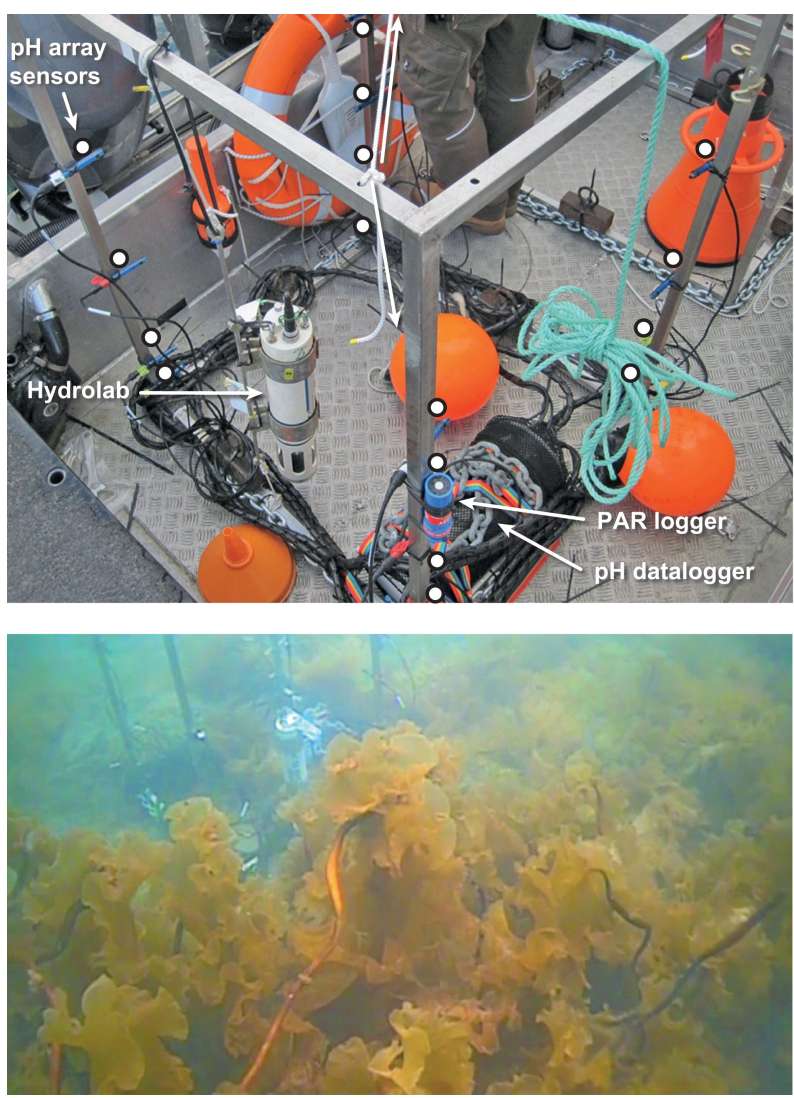

Figure A1. Photo of deployment frame with loggers shown on the deck of the boat (upper panel) and in situ in the Saccharina longicrurisdominated kelp forest (site \#1, central panel). Markings in upper panel show the array of $16 \mathrm{pH}$ sensors connected to a common $\mathrm{pH}$ logger; the Hydrolab instrument measuring salinity, temperature and oxygen; and a PAR logger (Odyssey). 

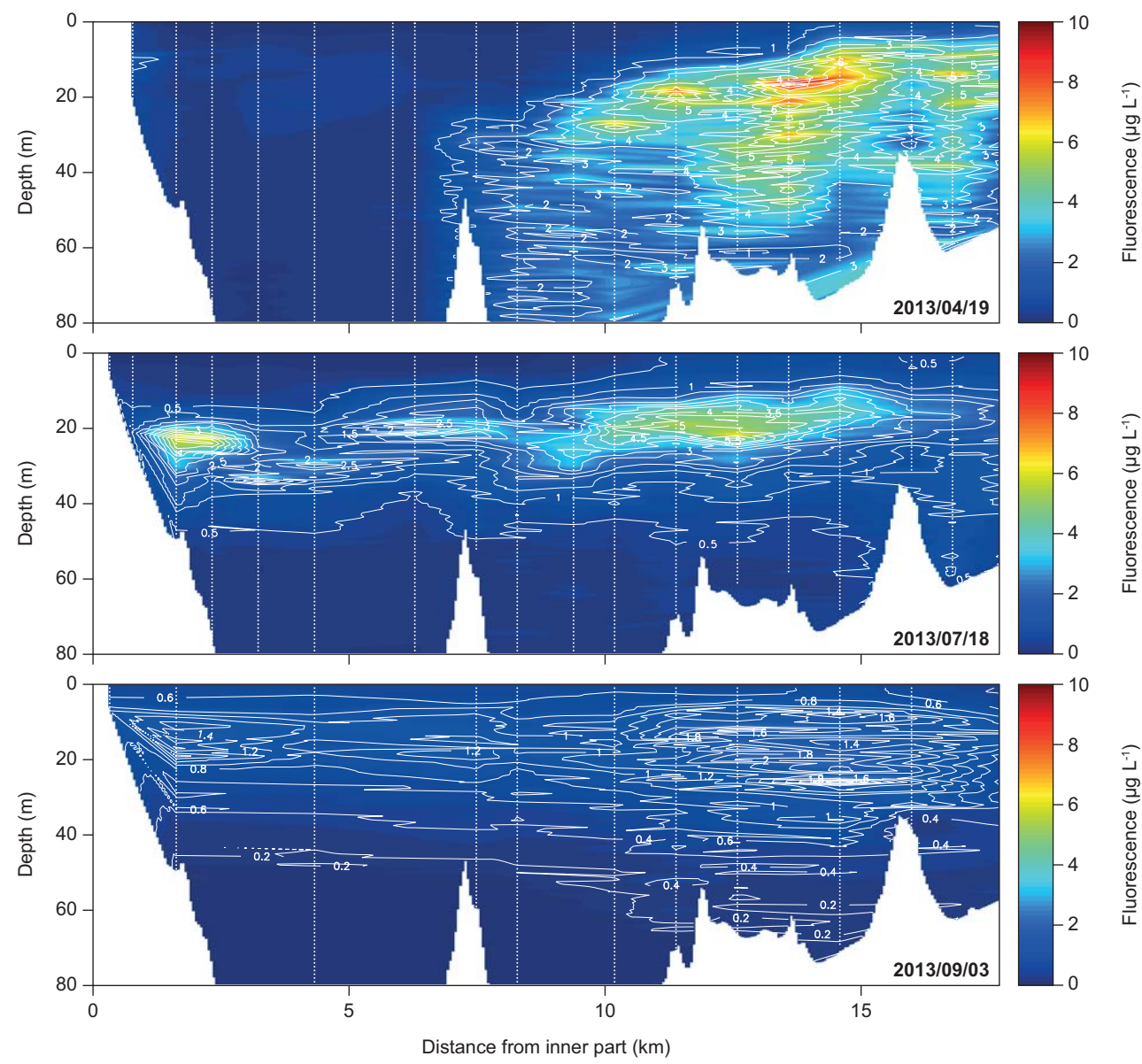

Figure A2. Fjord-scale variability in fluorescence in Kobbefjord, Nuuk, 19 April, 18 July and 3 September 2013. 

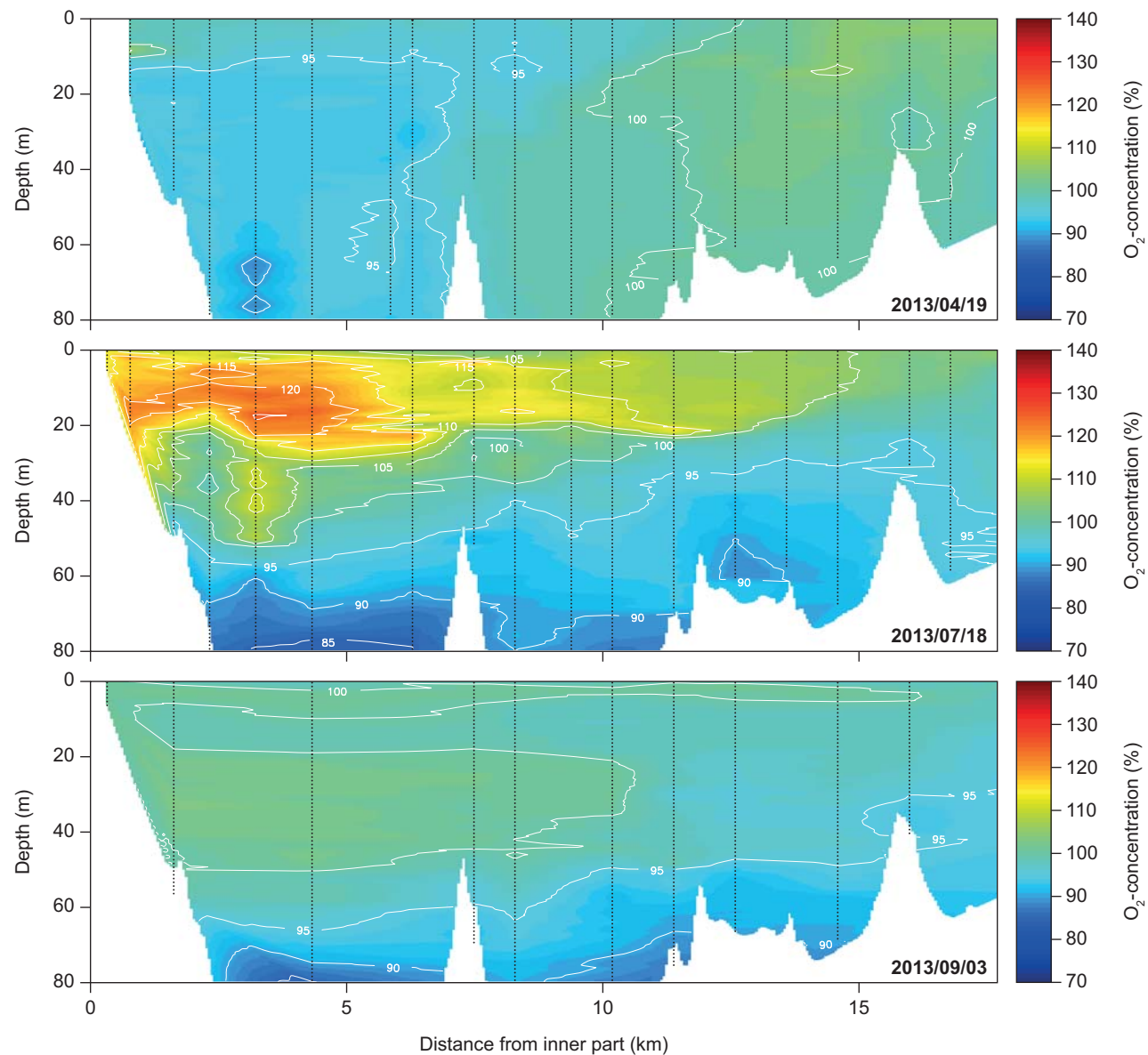

Figure A3. Fjord-scale variability in $\mathrm{O}_{2}$ concentration in Kobbefjord, Nuuk, 19 April, 18 July and 3 September 2013. 
Author contributions. Planning, field work, data processing and writing were carried out jointly, led by D. Krause-Jensen and C. M. Duarte, with L. Meire and M. K. Sejr responsible for fjord-scale surveys; I. E. Hendriks, M. K. Sejr, M. E. Blicher, C. M. Duarte and D. Krause-Jensen responsible for the various small-scale measurements; I. E. Hendriks and N. Marba for microscale measurements; N. Marba and D. Krause-Jensen for intertidal measurements; and M. E. Blicher for Greenland field facilities. Main idea: C. M. Duarte.

Acknowledgements. The study was funded by the Danish Environmental Protection Agency within the Danish Cooperation for Environment in the Arctic (DANCEA). L. Meire was funded by the Research Foundation Flanders (FWO aspirant grant) and by DEFROST as part of the Nordic Centres of Excellence (NCoE) programme. O. Geertz-Hansen, Greenland Climate Research Centre, Greenland Institute of Natural Resources, Nuuk, is thanked for help with field work. The study is also a contribution to the Greenland Ecosystem Monitoring programme (www.G-E-M.dk) and the Arctic Science Partnership (ASP, asp-net.org).

Edited by: J.-P. Gattuso

\section{References}

AMAP: AMAP Assessment 2013: Arctic Ocean Acidification, Arctic Monitoring and Assessment Programme (AMAP), Oslo, Norway, viii + 99 pp., ISBN - 978-82-7971-082-0, 2013.

Arendt, K. E., Juul-Pedersen, T., Mortensen, J., Blicher, M. E., and Rysgaard, S: A 5-year study of seasonal patterns in mesozooplankton community structure in a sub-Arctic fjord reveals dominance of Microsetella norvegica (Crustacea, Copepoda), J. Plank. Res., 35, 105-120, 2013.

Arrigo, K. R., van Dijken, G., and Pabi, S.: Impact of a shrinking Arctic ice cover on marine primary production, Geophys. Res. Lett., 35, 1-6, 2008.

Attard, K. M., Glud, R. N., McGinnis, D. F., and Rysgaard, S.: Seasonal rates of benthic primary production in a Greenland fjord measured by aquatic eddy correlationLimnol, Oceanography, 59, 1555-1569, 2014.

Björk, M., Axelsson, L., and Beer, S.: Why is Ulva intestinalis the only macroalga inhabiting isolated rock pools along the Swedish Atlantic coast? Mar. Ecol. Prog. Ser., 284, 109-116, 2004.

Blicher, M. E. and Sejr, M. K.: Abundance, oxygen consumption and carbon demand of brittle stars in Young Sound and the NE Greenland shelf, Mar. Ecol. Prog. Ser., 422, 139-144, 2011.

Blicher, M. E., Sejr, M. K., and Rysgaard, S.: High carbon demand of dominant macrozoobenthic species indicates their central role in ecosystem carbon flow in a sub-Arctic fjord, Mar. Ecol. Ser., 383, 127-140, 2009.

Blicher, M. E., Rysgaard, S., and Sejr, M. K.: Growth and production of sea urchin Strongylocentrotus droebachiensis in a highArctic fjord, and growth along a climatic gradient $\left(64\right.$ to $\left.77^{\circ} \mathrm{N}\right)$, Mar. Ecol.-Prog. Ser., 341, 89-102, 2007.

Blicher, M. E., Sejr, M. K., and Høgslund, S.: Population structure of Mytilus edulis in the intertidal zone in a sub-Arctic fjord, SW Greenland, Mar. Ecol. Prog. Ser., 487, 89-100, 2013.
Connell, S. and Russell, B. D.: The direct effects of increasing $\mathrm{CO}_{2}$ and temperature on non-calcifying organisms: increasing the potential for phase shifts in kelp forests, Proc. R. Soc. B, 277, 14091415, 2010.

Cornwall, C. E., Hepburn, C. D., McGraw, C. M., Currie, K. I., Pilditch, C. A., Hunter, K. A., Boyd, P. W., and Hurd, C. L.: Diurnal fluctuations in seawater $\mathrm{pH}$ influence the response of a calcifying macroalga to ocean acidification, Proc. R. Soc. B, 280, 20132201, doi:10.1098/rspb.2013.2201, 2013a.

Cornwall, C. E., Hepburn, C. D., Pilditch, C. A., and Hurd, C. L.: Concentration boundary layers around complex assemblages of macroalgae: Implications for the effects of ocean acidification on understorey coralline algae, Limnol. Oceanogr., 58, 121-130, $2013 b$.

De Beer, D. and Larkum, A. W. D.: Photosynthesis and calcification in the calcifying algae Halimeda discoidea studied with microsensors, Plant Cell Environ., 24, 1209-1217, 2001.

Delille, B., Delille, D., Fiala, M., Prevost, C., and Frankignoulle, M.: Seasonal changes of $p \mathrm{CO}_{2}$ over a subantarctic Macrocystis kelp bed, Polar Biol., 23, 706-716, 2000.

Delille, B., Borges, A. V., and Delille, D.: Influence of giant kelp beds (Macrocystis pyrifera) on diel cycles of $p \mathrm{CO}_{2}$ and DIC in the Sub-Antarctic coastal area, Estuar. Coast Shelf Sci., 81, 114122., 2009.

Dickson, A. G. and Millero, F. J.: A comparison of the equilibrium constants for the dissociation of carbonic acid in seawater media, Deep-Sea Res., 34, 1733-1743, 1987.

Dickson, A. G., Sabine, C. L., and Christian, J. R.: Guide to best practices for ocean $\mathrm{CO}_{2}$ measurements, PICES Special Publication, 191 pp., 2007.

Duarte, C., Hendriks, I., Moore, T., Olsen, Y., Steckbauer, A., Ramajo, L., Carstensen, J., Trotter, J., and McCulloch, M.: Is Ocean Acidification an Open-Ocean Syndrome? Understanding Anthropogenic Impacts on Seawater pH, Estuar. Coast., 36, $221-$ 236, 2013.

Fabry, V. J., McClintock, J. B., Mathis, J. T., and Grebmeier, J. M.: Ocean Acidification at High Latitudes: The Bellweather, Oceanography, 22, 160-171, 2009.

Frieder, C. A., Nam, S. H., Martz, T. R., and Levin, L. A.: High temporal and spatial variability of dissolved oxygen and $\mathrm{pH}$ in a nearshore California kelp forest, Biogeosciences, 9, 3917-3930, doi:10.5194/bg-9-3917-2012, 2012.

Frieder, C. A., Gonzales, J. P., Bockmon, E. E., Navarro, M. O., and Levini, L. A.: Can variable $\mathrm{pH}$ and low oxygen moderate ocean acidification outcomes for mussel larvae?, Glob. Change Biol., 20, 754-764, 2014.

Glud, R. N., Berg, P., Hume, A., Batty, P., Blicher, M. E., Lennert, $\mathrm{K}$., and Rysgaard, S.: Benthic $\mathrm{O}_{2}$ exchange across hard-bottom substrates quantified by eddy correlation in a sub-Arctic fjord, Mar. Ecol.-Prog. Ser., 417, 1-12, 2010.

Helm, V., Humbert, A., and Miller, H.: Elevation and elevation change of Greenland and Antarctica derived from CryoSat-2, Cryosphat, 8, 1539-1559, 2014

Hendriks, I. E., Olsen, Y. S., Ramajo, L., Basso, L., Steckbauer, A., Moore, T. S., Howard, J., and Duarte, C. M.: Photosynthetic activity buffers ocean acidification in seagrass meadows, Biogeosciences, 11, 333-346, doi:10.5194/bg-11-333-2014, 2014.

Hofmann, G. E., Smith, J. E., Johnson, K. S., Send, U., Levin, L. A., Micheli, F., Paytan, A., Price, N. N., Peterson, B., Takeshita, 
Y., Matson, P. G., Crook, E. D., Kroeker, K. J.., Gambi, M. C., Rivest, E. B., Frieder, C. A., Yu, P. C., and Martz, T. R.: HighFrequency Dynamics of Ocean $\mathrm{pH}$ : A Multi-Ecosystem Comparison, PLoS ONE, 6, e28983, doi:10.1371/journal.pone.0028983, 2011.

Høgslund, S., Sejr, M. S., Wiktor, J. Jr., Blicher, M. E., and Wegeberg, S.: Intertidal community composition along rocky shores in Southwest Greenland: a quantitative approach, Polar Biol., 37, 1549-1561, 2014.

Hurd, C. L. and Pilditch C. A.: Flow-induced morphological variations affect diffusion boundary-layer thickness of Macrocystis pyrifera (Heterokontophyta, Laminariales), J. Phycol., 47, 341$351,2011$.

Hurd, C. L., Cornwall, C. E., Currie, K., Hepburn, C. D., McGraw, C. M., Hunter, K. A., and Boyd P. W.: Metabolically-induced $\mathrm{pH}$ fluctuations by some coastal calcifiers exceed projected 22nd century ocean acidification: a mechanism for differential susceptibility?, Glob. Change Biol., 17, 3254-3262, 2011.

Jueterbock, A., Tyberghein, L., Verbruggen, H., Coyer, J. A., Olsen, J. L., and Hoarau, G.: Climate change impact on seaweed meadow distribution in the North Atlantic rocky intertidal, Ecol. Evol., 3, 1356-1373, 2013.

Krause-Jensen, D. and Duarte, C. M. Expansion of vegetated coastal ecosystems in the future Arctic, Front. Mar. Sci., 1, 77, doi:10.3389/fmars.2014.00077, 2014

Krause-Jensen, D., Marbà, N., Olesen, B., Sejr, M. K., Christensen, P. B., Rodrigues, J., Renaud, P. E., Balsby, T. J. S., and Rysgaard, S.: Seasonal sea ice cover as principal driver of spatial and temporal variation in depth extension and annual production of kelp in Greenland, Glob. Change Biol., 18, 2981-2994, 2012.

Krause-Jensen, D., Duarte, C. M., Hendriks, I. E., Meire, L., Blicher, M. E., Marbà, N., and Sejr, M. K.: Nested scales of pH variability in sub-Arctic Kobbefjord, SW Greenland, DIGITAL.CSIC, available at: http://hdl.handle.net/10261/112946, last access: 27 March 2015.

Kroeker K. J., Kordas, R. L., Crim, R., Hendriks, I. E., Ramajos, L., Singh, G. S., Duarte, C. M., and Gattuso, J.-P.: Impacts of ocean acidification on marine organisms: quantifying sensitivities and interaction with warming, Glob. Change Biol., 19, 1884-1896, 2013.

Mehrbach, C., Culberson, C. H., Hawley, J. E., and Pytkowicz, R. M.: Measurement of the apparent dissociation constants of carbonic acid in seawater at atmospheric pressure, Limnol. Oceanogr., 18, 897-907, 1973.

Meire, L., Søgaard, D. H., Mortensen, J., Meysman, F. J. R., Soetaert, K., Arendt, K. E., Juul-Pedersen, T., Blicher, M. E., and Rysgaard, S.: Glacial meltwater and primary production are drivers of strong $\mathrm{CO}_{2}$ uptake in fjord and coastal waters adjacent to the Greenland Ice Sheet, Biogeosciences, 12, 2347-2363, doi:10.5194/bg-12-2347-2015, 2015.

Mercado J. M. and Gordillo F. J.: Inorganic carbon acquisition in algal communities: are the laboratory data relevant to the natural ecosystems?, Photosynth. Res., 109, 257-267, 2011.

Middelboe, A. L. and Hansen, P. J.: Direct effects of pH and inorganic carbon on macroalgal photosynthesis and growth, Mar. Biol. Res., 3, 134-144, 2007.
Müller, R., Laepple, T., Bartsch,I., and Wiencke, C. Impact of oceanic warming on the distribution of seaweeds in polar and cold-temperate waters, Bot. Mar., 52, 617-638, 2009.

Olesen, B., Krause-Jensen, D., Marbà, N., and Christensen, P. B.: Eelgrass (Zostera marina L.) meadows in subarctic Greenland: Dense meadows with slow biomass turnover, Mar. Ecol. Prog. Ser., 518, 107-121, 2015.

Olischläger M., Bartsch, I., Gutow, L., and Wiencke, C.: Effects of ocean acidification on different life-cycle stages of the kelp Laminaria hyperborea (Phaeophyceae), Bot. Mar., 55, 511-525, 2012.

Parsons, T. R., Maita, Y., and Lalli, C. M.: A Manual of Chemical and Biological Methods for Seawater Analysis, Pergamon Press, 173 pp., 1984.

Pierrot, D. E. L. and Wallace, D. W. R.: MS Excel Program Developed for $\mathrm{CO}_{2}$ System Calculations. ORNL/CDIAC-105a. Carbon Dioxide Information Analysis Center, Oak Ridge National Laboratory, US Department of Energy, Oak Ridge, Tennessee, 2006.

Popova, E. E., A. Yool, A. C. Coward, F. Dupont, C. Deal, S. Elliott, E. Hunke, M. Jin, M. Steele, and J. Zhang: What controls primary production in the Arctic Ocean? Results from an intercomparison of five general circulation models with biogeochemistry, J. Geophys. Res., 117, C00D12, doi:10.1029/2011JC007112, 2012.

Richter, A., Rysgaard, S., Dietrich, R., Mortensen, J., and Petersen, D.: Coastal tides in West Greenland derived from tide gauge records, Ocean Dyn., 61, 39-49, 2011.

Riera, P., Escaravage, C., and Leroux, C.: Trophic ecology of the rocky shore community associated with the Ascophyllum nodosum zone (Roscoff, France): a $\delta^{13} \mathrm{C}$ vs. $\delta^{15} \mathrm{~N}$ investigation, Estuar. Coast Shelf Sci., 81, 143-148, 2009.

Sejr, M. K., Sand, M. K., Jensen, K. T., Petersen, J. K., Christensen, P. B., and Rysgaard, S.: Growth and production of Hiatella arctica (Bivalvia) in a high-Arctic fjord (Young Sound, Norhteast Greenland), Mar. Ecol. Prog. Ser., 244, 163-169, 2002.

Sejr, M. K., Krause-Jensen, D., Rysgaard, S., Sørensen, L. L., Christensen, P. B., and Glud, R. N.: Air-sea flux of $\mathrm{CO}_{2}$ in arctic coastal waters influenced by glacial melt water and sea ice, Tellus B, 63, 815-822, 10.1111/j.1600-0889.2011.00540.x, 2011.

Sejr, M. K., Krause-Jensen, D., Dalsgaard, T., Ruiz-Halpern, S., Duarte, C. M., Middelboe, M., Glud, R. N., Bendtsen, J., and Rysgaard, S.: Seasonal dynamics of autotrophic and heterotrophic plankton metabolism and $p \mathrm{CO}_{2}$ in a subarctic Greenland fjord, Limnol. Oceanogr., 59, 1764-1778, 2014.

Slagstad, D., Ellingsen, I. H., and Wassmann, P: Evaluating primary and secondary production in an Arctic Ocean void of summer sea ice: an experimental simulation approach, Prog. Oceanogr., 90, 117-131, 2011.

Takahashi, T., Olafsson, J., Goddard, J. G., Chipman, D. W., and Sutherland, S. C.: Seasonal variation of $\mathrm{CO}_{2}$ and nutrients in the high-latitude surface oceans: A comparative study, Global Biogeochem. Сy., 7, 843-878, 1993.

Thomsen, J., Casties, I., Pansch, C., Körtzinger, A., and Melzner, F.: Food availability outweighs ocean acidification effects in juvenile Mytilus edulis: laboratory and field experiments, Glob. Change Biol., 19, 1017-1027, 2013. 